\title{
Contrasting responses to salinity and future ocean acidification in arctic populations of the amphipod Gammarus setosus
}

Brown, James; Whiteley, Nia; Bailey, Allison; Graham, Helen; Hop, Haakon ; Rastrick, Samuel

\section{Marine Environmental Research}

DOI:

10.1016/j.marenvres.2020.105176

Published: 01/12/2020

Peer reviewed version

Cyswllt i'r cyhoeddiad / Link to publication

Dyfyniad o'r fersiwn a gyhoeddwyd / Citation for published version (APA):

Brown, J., Whiteley, N., Bailey, A., Graham, H., Hop, H., \& Rastrick, S. (2020). Contrasting responses to salinity and future ocean acidification in arctic populations of the amphipod Gammarus setosus. Marine Environmental Research, 162, [105176].

https://doi.org/10.1016/j.marenvres.2020.105176

\footnotetext{
Hawliau Cyffredinol / General rights

Copyright and moral rights for the publications made accessible in the public portal are retained by the authors and/or other copyright owners and it is a condition of accessing publications that users recognise and abide by the legal requirements associated with these rights.

- Users may download and print one copy of any publication from the public portal for the purpose of private study or research.

- You may not further distribute the material or use it for any profit-making activity or commercial gain

- You may freely distribute the URL identifying the publication in the public portal ?
}

Take down policy

If you believe that this document breaches copyright please contact us providing details, and we will remove access to the work immediately and investigate your claim. 
1 Contrasting responses to salinity and future ocean acidification in Arctic

2 populations of the amphipod Gammarus setosus

3 James Brown ${ }^{1}$, Nia M. Whiteley ${ }^{2}$, Allison M. Bailey ${ }^{3}$, Helen Graham $^{4}$, Haakon Hop ${ }^{3}$ and

$4 \quad$ Samuel. P.S. Rastrick ${ }^{4}$

5

$6{ }^{1}$ Department of Biological Sciences, University of Chester, Thomas Building, Parkgate

7 Road, Chester, CH1 4BJ, UK

$8 \quad{ }^{2}$ School of Natural Sciences, Bangor University, Deiniol Road, Bangor, Gwynedd. LL57

$9 \quad 2 \mathrm{UW}, \mathrm{UK}$

$10{ }^{3}$ Norwegian Polar Institute, Fram Centre, 9296, Troms $\varnothing$, Norway

$11{ }^{4}$ Institute of Marine Research, P.O. Box 1870, Nordnes, 5817, Bergen, Norway

12

13 Contact for Correspondence: James Brown; brown.j@ chester.ac.uk 


\section{Abstract}

Climate change is leading to alterations in salinity and carbonate chemistry in arctic/sub-arctic marine ecosystems. We examined three nominal populations of the circumpolar arctic/subarctic amphipod, Gammarus setosus, along a salinity gradient in the Kongsfjorden/Krossfjorden area of Svalbard. Field and laboratory experiments assessed physiological (haemolymph osmolality and gill $\mathrm{Na}^{+} / \mathrm{K}^{+}$-ATPase activity, NKA) and energetic responses (metabolic rates, $\mathrm{MO}_{2}$, and Cellular Energy Allocation, CEA). In the field, all populations had similar osmregulatory capacities and $\mathrm{MO}_{2}$, but lower-salinity populations had lower CEA. Reduced salinity $(\mathrm{S}=23)$ and elevated $p \mathrm{CO}_{2}(\sim 1000 \mu \mathrm{atm})$ in the laboratory for one month increased gill NKA activities and reduced CEA in all populations, but increased $\mathrm{MO}_{2}$ in the higher-salinity population. Elevated $p \mathrm{CO}_{2}$ did not interact with salinity and had no effect on NKA activities or CEA, but reduced $\mathrm{MO}_{2}$ in all populations. Reduced CEA in lower-rather than higher-salinity populations may have longer term effects on other energy demanding processes (growth and reproduction).

Key words: Arctic; amphipods; cellular energy budgets; metabolic rates; ocean acidification; salinity; Kongsfjorden; Svalbard

\section{Introduction}

Salinity change is a prominent feature of climate-driven environmental change in Arctic and sub-arctic marine ecosystems. Reductions in sea surface salinity are occurring at higher latitudes because of increasing precipitation, as well as increasing seasonal freshwater input from melting glaciers and permafrost (Callaghan et al., 2011). Within fjord systems of a similar size to Kongsfjorden and Krossfjorden in Svalbard $\left(78-79^{\circ} \mathrm{N}\right)$, i.e. $20-30 \mathrm{~km}$ long $\times 5-10 \mathrm{~km}$ wide, such changes are altering water flow, and salinity gradients along coastal margins and with depth (Tverberg et al., 2019). Adjusting to salinity change is a considerable challenge to 
marine invertebrates, as exposure to reduced salinity increases osmotic gradients across the body surface resulting in the passive influx of water and the loss of ions (Henry et al., 2012). Subsequent changes to extra- and intra-cellular osmolality influences cell volume control and therefore cell function, and many species living in habitats characterised by fluctuating salinities osmoregulate to counteract these effects. Osmoregulatory mechanisms can involve an increase in ion-transporting capacities, the mobilisation of organic osmolytes, and a decrease in body surface permeability (Henry et al., 2012; Rivera-Ingraham et al., 2017). In primarily marine crustaceans, low salinity exposure is dominated by an increase in ion transporting capacities, mainly via an increase in branchial $\mathrm{Na}^{+} / \mathrm{K}^{+}$-ATPase activities in order to drive the transepithelial movement of ions (Lucu and Towle, 2003). As $\mathrm{Na}^{+} / \mathrm{K}^{+}$-ATPase activity is considered a major energy consuming process (Pan et al., 2015; Sokolova et al., 2012), and an important component of the increase in metabolic rate observed in many osmoregulating crustaceans (Normant et al., 2004; Normant and Lamprecht, 2006; Jimenez and Kinsey, 2015), an increased reliance on elevated branchial $\mathrm{Na}^{+} / \mathrm{K}^{+}$-ATPase activity at low salinity could be energetically demanding and influence energy budgets.

Arctic/sub-arctic coastal regions are also experiencing gradual elevations in $p \mathrm{CO}_{2}$ and reductions in seawater $\mathrm{pH}$ and carbonate concentrations due to ocean acidification (Calderia and Wickett, 2003; Orr et al., 2005). Projected changes in seawater surface pH and calcium carbonate saturation are greater in the Arctic mainly due to freshening and resulting decreases in $\mathrm{H}^{+}$buffering capacity, as well as increased $\mathrm{CO}_{2}$ uptake as the sea ice retreats (Steinacher et al., 2009). The survival of marine invertebrates under conditions of elevated $p \mathrm{CO}_{2}$ is closely associated with their ability to regulate extracellular $\mathrm{pH}$, or acid-base status, despite external changes in seawater carbon chemistry (Wittman and Pörtner, 2013). This in turn helps to preserve intracellular $\mathrm{pH}$, which is particularly important for biomineralisation processes in epithelial cells responsible for the formation of calcified skeletons and shells. Both $\mathrm{pH}$ 
regulation and biomineralisation involve the transport of ions across epithelia driven by energy consuming ion pumps, suggesting that the ability to compensate for external elevations in $p \mathrm{CO}_{2}$ is energetically challenging (Wittman and Pörtner, 2013). In crustaceans, where pH regulation has been studied in some detail, compensation for external elevations in $p \mathrm{CO}_{2}$ occurs via the exchange of acid-base equivalents across the gill epithelia using the same mechanisms as those used for osmoregulation (Wheatly and Henry, 1992; Whiteley et al., 2001; Whiteley, 2011). As a result, strong osmoregulators are considered to be less vulnerable to ocean acidification, although extracellular acid-base responses to elevated $\mathrm{CO}_{2}$ can vary according to external salinity (Wheatly and Henry, 1992; Whiteley et al., 2001). Ion regulation and metabolic responses to elevated $\mathrm{CO}_{2}$ also vary among populations occupying different salinity regimes, suggesting population-related differences in energy expenditure. Such differences were demonstrated in the isopod crustacean, Idotea baltica, as elevated $\mathrm{CO}_{2}$ increased metabolic rates in a population inhabiting dilute seawater, but depressed metabolic rates in a marine population (Wood et al., 2016). As both $\mathrm{CO}_{2}$ and salinity fluctuations co-occur in the field and are predicted to continue to change in the future, it is important to study the energetic repercussions in those species generally accepted to be tolerant of the changes. It is possible that resulting shifts in energy budgets could lead to trade-offs with other energy demanding processes, such as growth and reproduction, and have a negative impact on species at the population level (Widdecombe and Spicer, 2008).

Fjords such as Kongsfjorden, Svalbard, have been experiencing changes in seasonal stratification of both temperature and salinity because of increased melting of the glaciers and changes in patterns of freshwater run-off (Svendsen et al., 2002; Tverberg et al., 2019). Variations in the extent of mixing with the adjacent warm, saline Atlantic current and cool, relatively fresh Arctic waters are also occurring. In the summer, salinity drops to 28 in the surface waters close to the glaciers in the inner fjord, and is 30 towards the middle (i.e. KB3; 
Svendsen et al., 2002). Gammarid amphipod crustaceans are particularly abundant in the fjord and surrounding areas and are important components of the Arctic food web as food for fish, birds and seals (e.g. Leinaas and Ambrose, 1999). Two species are found in great abundance along the shore-line: Gammarus setosus, a circumpolar arctic/subarctic species that is restricted to a circumpolar distribution, only extending as far south as the Bay of Fundy of New Brunswick (Steele and Steele, 1970) and to Jan Mayen and Northern Norway in the east Atlantic (Gulliksen et al., 2003; Vader and Tandberg, 2019); and Gammarus oceanicus, a boreal/cool-temperate species that has expanded north after the last glacial maxima (Costa et al., 2009). Both co-exist along the shore of Kongsfjorden, but over the last 10 years, under general warming conditions, G. oceanicus has expanded its range along the shore and $G$. setosus has shifted towards the head of the fjords into cooler water of lower salinity (Weslawski et al., 2011; 2018). It appears that in order for G. setosus to escape warming conditions, it faces another challenge in the form of seawater dilution, and yet several populations occupy the south-eastern shore from Ny-Ålesund to Raudvika (inner fjord) where salinities range from 30 down to 17. Currently, it is unknown whether G. setosus will survive the lower salinities under conditions of increasing $\mathrm{CO}_{2}$ levels.

The purpose of the study was to determine ion-transporting capacities and energy budgets of G. setosus inhabiting different salinity sites within the Kongsfjorden-Krossfjorden system in Svalbard. Herein, G. setosus from these sites are referred to nominally as populations, although it is unknown whether any observed physiological differences between sites are due to phenotypic plasticity or local adaptation. As adaptation is dependent on the rate of gene flow between sites being lower than rates of selection, the migration of only a few individuals per generation possibly compromises genetic differences and the protostructuring of true populations across environmental gradients (reviewed by Rastrick et al., 2018b). Given that osmoregulation is energetically demanding, we were interested in examining whether 
populations living in the inner fjord and experiencing lower salinities have higher iontransporting capacities and lower energy budgets compared with a population in the outer fjord inhabiting higher relative salinities. We were also interested in investigating whether habitat salinity influences energy budgets in G. setosus exposed to the added complication of elevated $\mathrm{CO}_{2}$. To this end, G. setosus were sampled in the field to determine in situ energy budgets, and then in the laboratory under controlled conditions to specifically study the combined effects of reduced salinity to the values experienced in the inner fjord and near future elevations in $\mathrm{CO}_{2}$. Osmoregulatory capacity was determined as changes in coxal gill $\mathrm{Na}^{+} / \mathrm{K}^{+}$ATPase activity and the energetic consequences were examined via changes in metabolic rate and also changes in cellular energy allocation. The latter has been used to examine changes in energy status over longer time periods than most metabolic rate analyses, and is regularly used in field-based studies (De Coen and Janssen, 1997). Overall, the study aimed to establish whether energy budgets, and hence sensitivities, are equally impacted by changes in environmental salinity and $\mathrm{CO}_{2}$ across populations of a sub-arctic species occupying different sites along a salinity gradient.

\section{Material and methods}

\subsection{Animal collection and acclimation}

Adult G. setosus (215 $\pm 8.6 \mathrm{mg})$, morphologically identified according to Lincoln (1979), were collected in August 2018 from the intertidal zone at two locations in Kongsfjorden (Blomstrandhalvøya: 7859’11.4’, 12¹3’56.8”; near Kongsvegen glacier: 7852’51.7’, $\left.12^{\circ} 22^{\prime} 48.1^{\prime \prime}\right)$ and one location on the Mitrahalvøya side of Krossfjorden at the entrance of

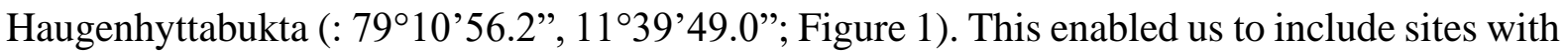
differing salinities. Individuals from these sites will hereafter be referred to as populations. Field studies involved the collection of 30 amphipods at random from the shore for each 
population. At each site, metabolic rate was determined on the shore on 9 individual amphipods within $\sim 1 \mathrm{hr}$ of collection (detailed in the next subsection). The salinity, temperature, and $\mathrm{pH}$ of shore surface water $(<1 \mathrm{~m})$ was also measured upon collection of the amphipods, using a handheld multimeter (labquest 2, Vernier, Beaverton, USA), and are displayed in Table 1. Water samples $(10 \mu \mathrm{l} ; \mathrm{n}=3)$ were also taken for the measurement of medium osmolality. Amphipods were transported by boat for approximately 30 min to the Kings Bay Marine Laboratory in closed $500 \mathrm{ml}$ plastic tanks inside a cool box in water at the appropriate capture salinity and temperature. On arrival the water in the transportation tanks was immediately aerated and amphipods were sampled for haemolymph osmolality $(n=8)$ before a further 20 animals were snap frozen in liquid nitrogen and stored at $-80^{\circ} \mathrm{C}$. These amphipods were used for the determination of coxal gill $\mathrm{Na}^{+} / \mathrm{K}^{+}$-ATPase activity $(\mathrm{n}=12$ per population) and cellular energy budgets ( $\mathrm{n}=8$ per population). The maximum time from collection to haemolymph sampling was 3 hours.

.

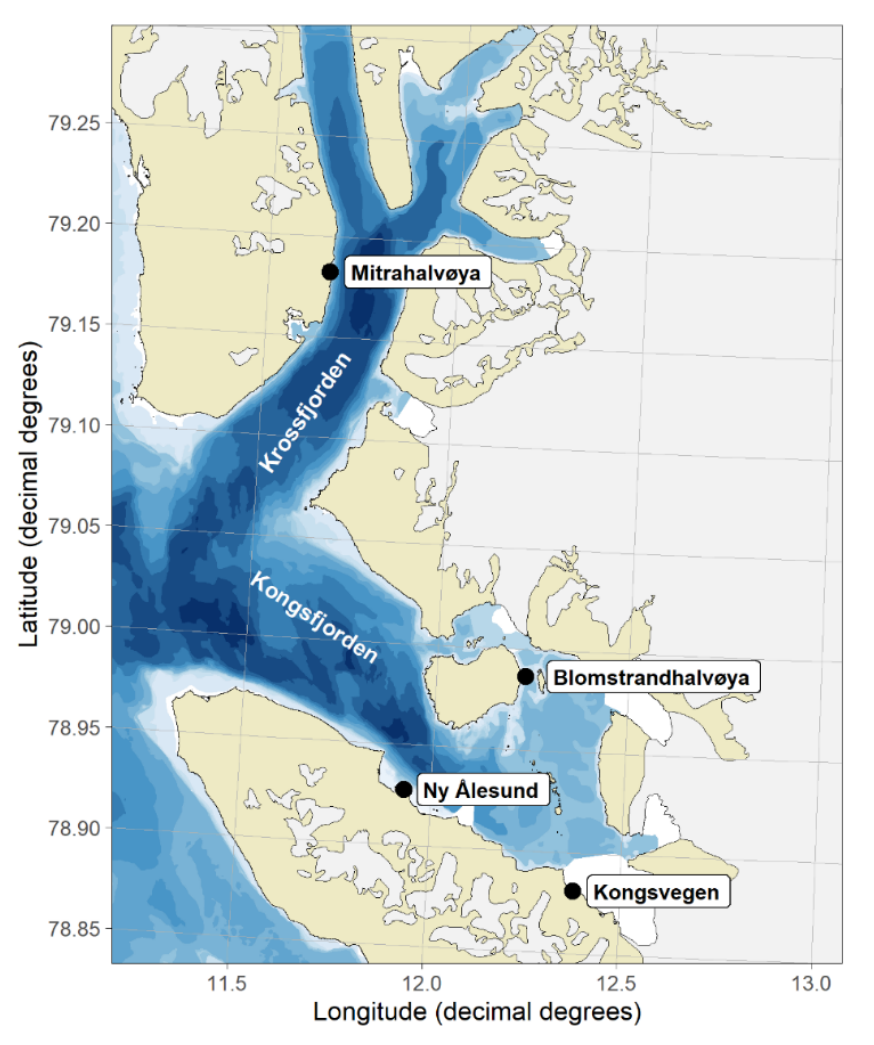


Figure 1. Location of the collection sites for the three populations of Gammarus setosus in Kongsfjorden and Krossfjorden, Svalbard (land map from Norwegian Polar Institute, bathymetry from Norwegian Mapping Authority, Vihtakari, 2019).

\begin{tabular}{cccc}
\hline Collection Site & Salinity & $\mathrm{pH}$ & $\begin{array}{c}\text { Temperature } \\
\left({ }^{\circ} \mathrm{C}\right)\end{array}$ \\
\hline Mitrahalvøya & 30 & 8.16 & 4.1 \\
Blomstrandhalvøya & 23 & 8.16 & 4.7 \\
Kongsvegen & 26 & 8.12 & 3.7 \\
\hline
\end{tabular}

Table 1. Environmental seawater measurements at the time of collection from each of the three collection sites.

A further 120 individuals per site were maintained in aerated water corresponding to the in situ temperature and salinity at each collection point for up to $72 \mathrm{~h}$ before being transported back to the Institute of Marine Research Austevoll Station, Norway, between sheets of tissue paper soaked in water at the appropriate capture salinity and temperature (after Rastrick and Whiteley 2011; 2013). Transport time was 12 hours. After transit, the animals were left to recover for $72 \mathrm{~h}$ in aerated water held at the appropriate capture salinity and temperature prior to acclimation to experimental conditions. For the experimental exposures, treatments consisted of two salinity levels (30 and 23, representing the natural range at which animals were collected) and two $\mathrm{pCO}_{2}$ levels (400 and $1000 \mu \mathrm{atm}$, representing present and predicted 'end of the century' levels) in a fully crossed design with triplicate holding tanks per treatment. Ten G. setosus from each population were assigned to each holding tank $(600 \mathrm{ml} ; \mathrm{n}$ $=30$ per treatment). Seawater salinity and $p \mathrm{CO}_{2}$ levels were changed from ambient to the final treatment conditions over three days. This corresponded to a $\mathrm{pH}$ change of $0.15 \mathrm{pH}$ units per day and up to 3 salinity units per day. Unfiltered seawater collected from the intertidal shore (Austevoll, Norway) and unchlorinated freshwater (source: Water area West-Austevoll) were mixed to create the different salinity levels. A nominal control $p \mathrm{CO}_{2}$ value of $400 \mu \mathrm{atm}$ was 
selected as this corresponds to the natural habitat $p \mathrm{CO}_{2}$ level experienced by the amphipods at the time of collection. The predicted future elevated $p \mathrm{CO}_{2}$ level of $1000 \mu \mathrm{atm}$ (RCP8.5 2100 $p \mathrm{CO}_{2}$ projection; Van- Vuuren et al., 2011) was achieved by continuously bubbling a premixed air- $\mathrm{CO}_{2}$ gas mixture into each of the replicate high $\mathrm{CO}_{2}$ treatment tanks separately. A $p \mathrm{CO}_{2}$ of $1000 \mu \mathrm{atm}$ was controlled at each salinity as explained by Rastrick et al. (2018a). In summary, predetermined seawater $\mathrm{pH}$ levels, adjusted for temperature, salinity and total alkalinity $\left(\mathrm{A}_{\mathrm{T}}\right)$ for each treatment were calculated using free access $\mathrm{CO}_{2} \mathrm{SYS}$ (Lewis and Wallace 1998; $(30=\mathrm{pH} 7.643 ; 23=\mathrm{pH} 7.567)$.

Treatment water was replaced every two days with pre-mixed seawater adjusted to the respective treatment conditions. The system was installed in a temperature-controlled room maintained at $5^{\circ} \mathrm{C}$ throughout the experiment. Temperature, $\mathrm{pH}$, and salinity in each individual tank were recorded daily using a handheld multimeter (WTW $3110 \mathrm{pH}$ meter and WTW LF340 Conductivity meter). The $\mathrm{pH}$ and conductivity electrodes were calibrated twice weekly with NIST certified $\mathrm{pH}$ buffer solutions and standard solutions, respectively. A single water sample $(10 \mu \mathrm{l})$ was taken from each holding tank weekly for the measurement of medium osmolality. $\mathrm{A}_{\mathrm{T}}$ was also measured weekly by titration (TIM840 titration manager, TitraLab). Values for the physico-chemical parameters and the associated carbonate chemistry values for this system are presented in Table 2. The herbivorous amphipods were fed a diet of algal fish food $a d$ libitum (Hikari Mini algae wafers, Kyorin Co. LTD, Japan) and uneaten food was removed after 8 hours. Following 28 days of acclimation to treatment conditions, amphipods were sampled to determine metabolic rates $(n=9$ per treatment), haemolymph osmolality $(n=6$ per treatment), coxal gill $\mathrm{Na}^{+} / \mathrm{K}^{+}$-ATPase activities $(\mathrm{n}=12$ per treatment $)$ and CEA $(n=9$ per treatment) as for the field studies. Amphipods were starved for $24 \mathrm{~h}$ before sampling to minimize differences in metabolic rate due to feeding status. 


\begin{tabular}{|c|c|c|c|c|}
\hline $\begin{array}{l}\text { Nominal } p \mathrm{CO}_{2} \text { treatment } \\
(\mu \mathrm{atm})\end{array}$ & 400 & 400 & 1000 & 1000 \\
\hline Nominal Salinity Treatment & 23 & 30 & 23 & 30 \\
\hline$p \mathrm{CO}_{2}$ treatment $(\mu \mathrm{atm})$ & $390.8(1.768)^{\mathrm{a}}$ & $427.4(2.675)^{\mathrm{a}}$ & $901.0(6.485)^{\mathrm{b}}$ & $870.7(7.389)^{b}$ \\
\hline Salinity & $22.96(0.007)^{\mathrm{a}}$ & $30.07(0.013)^{\mathrm{b}}$ & $22.96(0.006)^{\mathrm{a}}$ & $30.07(0.013)^{\mathrm{b}}$ \\
\hline $\begin{array}{l}\text { Temperature } \\
\left({ }^{\circ} \mathrm{C}\right)\end{array}$ & $4.569(0.015)$ & $4.578(0.016)$ & $4.589(0.016)$ & $4.572(0.016)$ \\
\hline $\begin{array}{c}\mathrm{A}_{\mathrm{T}} \\
\left.(\mu \mathrm{mol} \mathrm{kg})^{-1}\right)\end{array}$ & $1663(2.078)^{\mathrm{a}}$ & $2177(5.314)^{\mathrm{c}}$ & $1701(0.217)^{\mathrm{ab}}$ & $2160(10.41)^{\mathrm{bc}}$ \\
\hline $\mathrm{pH}$ & $7.947(0.002)^{\mathrm{c}}$ & $8.000(0.003)^{\mathrm{d}}$ & $7.613(0.003)^{\mathrm{a}}$ & $7.709(0.003)^{\mathrm{b}}$ \\
\hline DIC $\left(\mu \mathrm{mol} \mathrm{kg}{ }^{-1}\right)$ & $1607(2.058)^{\mathrm{a}}$ & $2069(5.142)^{b c}$ & $1713(0.609)^{a b}$ & $2137(10.53)^{\mathrm{c}}$ \\
\hline $\mathrm{HCO}_{3}^{-}\left(\mu \mathrm{mol} \mathrm{kg}{ }^{-1}\right)$ & $1533(1.981)^{\mathrm{a}}$ & $1958(4.898)^{b c}$ & $1637(0.422)^{\mathrm{ab}}$ & $2043(10.06)^{\mathrm{c}}$ \\
\hline $\mathrm{CO}_{3}^{2-}\left(\mu \mathrm{mol} \mathrm{kg}{ }^{-1}\right)$ & $51.30(0.204)^{\mathrm{c}}$ & $87.90(0.501)^{\mathrm{d}}$ & $25.40(0.179)^{\mathrm{a}}$ & $46.95(0.316)^{\mathrm{b}}$ \\
\hline$\Omega_{\mathrm{calc}}$ & $1.296(0.005)^{\mathrm{c}}$ & $2.152(0.012)^{\mathrm{d}}$ & $0.642(0.005)^{\mathrm{a}}$ & $1.149(0.008)^{\mathrm{b}}$ \\
\hline$\Omega_{\text {arag }}$ & $0.785(0.003)^{\mathrm{c}}$ & $1.342(0.008)^{\mathrm{d}}$ & $0.389(0.003)^{\mathrm{a}}$ & $0.717(0.005)^{\mathrm{b}}$ \\
\hline
\end{tabular}

217 Temperature, salinity and $\mathrm{pH}\left(\mathrm{NBS}\right.$ scale) were measured daily. Total alkalinity $\left(\mathrm{A}_{\mathrm{T}}\right)$ was measured weekly.

218 Different superscript letters indicate significant variation between treatments (ANOVA with Tukey HSD post

219 hoc or Kruskal-Wallis with Dunn-Bonferroni post hoc, $\mathrm{p}<0.05$ ).

Table 2. Physico-chemical seawater parameters from each of the four nominal $p \mathrm{CO}_{2}$ and salinity treatments over the 28-day exposure period. Values are means with SEM in parenthesis

\subsection{Determination of metabolic rate}

Oxygen uptake rates $\left(\mathrm{MO}_{2}\right)$ of amphipods in the field were measured on the beach where they were collected using sealed-chamber respirometers in a water bath of continuously circulating shore water to maintain in situ temperature. Individuals of $G$. setosus $(\mathrm{n}=9)$ from each population were carefully placed into individual chambers (volume $12.5 \mathrm{ml}$ ) filled with natural seawater from their respective sampling sites (Table 1). Chambers were then closed and oxygen as a $\%$ of air saturation was measured every 15 minutes using a non-invasive optical oxygen system (Fibox 4, PreSens) over a $1 \mathrm{~h} 45 \mathrm{~min}$ period. The first $1 \mathrm{~h}$ of measurements were discarded to avoid stress-related handling effects and measurements were made in the shade to minimise disturbance to the animals.

Oxygen uptake rate in the laboratory was measured using stop-flow respirometry after Rastrick and Whiteley (2011). In brief, 9 G. setosus from each treatment were placed into 
individual stop-flow respirometers (volume $19 \mathrm{ml}$ ) supplied with the same seawater as the respective treatment tanks. For each treatment, all 9 respirometers were run simultaneously along with a control respirometer without an amphipod. Animals were allowed $1 \mathrm{~h}$ to settle in the respirometers and to recover from handling stress before the seawater flow was stopped (R. Crichton, unpublished observations). The resulting decline in $\%$ oxygen saturation was measured continuously over a period of 45 minutes using a non-invasive optical oxygen system (Oxy-10 mini, PreSens; as in Calosi et al., 2013). Measurements in the laboratory were made in the dark to minimise disturbance to the animals. In all cases, magnetic stirrers were used to prevent the formation of $p \mathrm{O}_{2}$ gradients within the respirometers. The stirrers were separated from the animals by a perforated platform. After the end of each measurement, amphipods were blotted dry on tissue paper for body mass determination. partial pressure $\left(\mathrm{pO}_{2}\right)$ at relevant barometric pressure. All readings were taken above $17 \mathrm{kPa}$ to avoid the effects of hypoxia. A respirometer without an amphipod was included during each run as a control. Rates of oxygen uptake were calculated by converting decreases in $p \mathrm{O}_{2}$ into dissolved oxygen by multiplying with the oxygen solubility of seawater using coefficients adjusted for the effect of temperature and salinity (Benson and Krause, 1984). This was adjusted for time, respirometer volume, and any oxygen change in the control respirometer to give $\mathrm{ml} \mathrm{O}_{2} \mathrm{~h}^{-1}$. Mass specific rates of oxygen uptake were adjusted for body mass $\left(\mathrm{ml} \mathrm{O}_{2} \mathrm{~g}^{-1} \mathrm{~h}^{-}\right.$ $\mu \mathrm{mol} \mathrm{O} \mathrm{g}^{-1} \mathrm{~h}^{-1}$ 
259 All six pairs of coxal gills were removed from each individual with fine forceps and placed in ice cold SEI buffer (150 mM sucrose; $10 \mathrm{mM} \mathrm{Na} 2$ EDTA; $50 \mathrm{mM}$ imidazole, $\mathrm{pH}$ 7.3). To allow for sufficient material for gill enzyme activity to be measured, coxal gills from two animals were pooled ( $\mathrm{n}=6$ after samples were pooled). $\mathrm{Na}^{+} / \mathrm{K}^{+}$-ATPase activities were determined using the microassay developed by McCormick and Bern (1989), modified for use in crustaceans by Wilder et al. (2000), in which the hydrolysis of ATP is enzymatically linked to the oxidation of NADH. All samples were analysed within 3 months as preliminary investigations showed that $\mathrm{Na}^{+} / \mathrm{K}^{+}$-ATPase activities are unaffected by freezing within this timeframe (J Brown, unpublished observations). Protein concentrations were determined using the micro-modification of the Pierce BCA Protein Assay (Thermo Scientific). $\mathrm{Na}^{+} / \mathrm{K}^{+}$-ATPase enzyme activities were expressed as $\mu$ mol ADP produced $\mathrm{mg}^{-1}$ protein $\mathrm{h}^{-1}$.

\subsection{Haemolymph and Medium osmolality}

A single $10 \mu \mathrm{l}$ haemolymph sample was taken from the haemocoel by fine tipped glass capillary tube inserted through the membrane between the $7^{\text {th }}$ pereon segment and the $1^{\text {st }}$ pleopod segment to extract haemolymph via capillary action. The osmolality of each haemolymph and water sample was determined using a freezing-point osmometer (Osmomat 030, Gonotec GmbH, Berlin, Germany).

\subsection{Cellular energy budgets}

277 Cellular Energy Allocation (CEA) was measured on whole organism homogenates according to De Coen and Janssen (1997) with several modifications. Individual amphipods were ground into a fine powder in liquid nitrogen using a pre-cooled pestle and mortar and allocated into 4 smaller subsamples, one each to determine the different energy reserve fractions $\left(\mathrm{E}_{\mathrm{a}}\right.$; total lipids, proteins and carbohydrates), and the remainder to determine cellular energy consumption $\left(\mathrm{E}_{\mathrm{c}}\right)$ by first measuring mitochondrial electron transport system (ETS) activity. 
Lipid content was determined using the Sulpho-Phospho-Vanillin method of Bligh and Dyer

chloroform:methanol solution before being dissolved in sulphuric acid, and reacted with

vanillin in the presence of phosphoric acid. Protein content in the homogenates was determined using the micro-modification of the Pierce BCA Protein Assay (Thermo Scientific).

Carbohydrate content was determined using the anthrone-sulphuric acid method of Roe (1954) and Leyva et al. (2008) whereby carbohydrates are extracted and washed using trichloroacetic acid (TCA) before being reacted with an anthrone-sulphuric acid solution. The different energy reserve fractions, expressed as $\mu \mathrm{g} \mathrm{ml}^{-1}$ were transformed into energetic equivalents using their respective energy of combustion $\left(39.5 \mathrm{~J} \mathrm{mg}^{-1}\right.$ lipid, $24.0 \mathrm{~J} \mathrm{mg}^{-1}$ protein, $17.5 \mathrm{~J} \mathrm{mg}^{-1}$ glycogen; Gnaiger, 1983) and combined to give total energy available ( $\left.E_{\mathrm{a}}\right)$ in $\mathrm{J} \mathrm{mg}^{-1} \mathrm{ww}$. Energy consumed $\left(\mathrm{E}_{\mathrm{c}}\right)$ was determined from the activity of the electron transport system at the mitochondrial level according to Owens and King (1975). In brief, ETS activity was estimated kinetically at $20^{\circ} \mathrm{C}$ for 10 min by measuring the electron transmission rate of the mitochondrial ETS from physiological substrates (NADH, succinate and NADPH) to an artificial electron receptor (INT), which reduces to form formazan. The amount of formazan formed was calculated using the extinction coefficient of $15,900 \mathrm{M}^{-1} \mathrm{~cm}^{-1}$. Energy consumption $\left(\mathrm{E}_{\mathrm{c}}\right)$ was subsequently estimated from the conversion of formazan in $\mu$ moles to $\mu$ moles of $\mathrm{O}_{2}$ assuming

$1 \mu \mathrm{mol}$ of $\mathrm{O}_{2}$ per $2 \mu \mathrm{mol}$ of formazan formed (De Coen \& Janssen 1997), and then converted 302 into energetic equivalents using the oxyenthalpic equivalent of $484 \mathrm{~kJ} \mathrm{~mol}^{-1}$ (Gnaiger 1983; De Coen and Janssen 1997). Gómez et al. (1996) have demonstrated that ETS activity is unaffected by freezing. $E_{c}$ was expressed in $\mathrm{mJ} \mathrm{mg}^{-1} \mathrm{ww}^{-1} \mathrm{~h}^{-1}$. CEA was calculated as $\mathrm{E}_{\mathrm{a}} / \mathrm{E}_{\mathrm{c}}$.

\subsection{Statistical analysis}

Differences in the response variables measured amongst the populations in the field and 
tested for normality using the Shapiro-Wilk test and homogeneity of variance using the Levene's test. Parametric data was analysed using a one-way ANOVA with Tukey HSD for pairwise comparisons and non-parametric data was analysed using a Kruskal-Wallis test with Dunn-Bonferrroni post-hoc test for pairwise comparisons (SPSS, Version 25).

The effects of population, elevated $p \mathrm{CO}_{2}$ and/or reduced salinity (fixed factors) and the random factor (tank) on all of the response variables in the laboratory were tested using linear mixed effects (LMM) and general least square modelling (GLS, Zuur et al., 2009) in RStudio version 1.1.383 (RStudio Team, 2016). LMM and GLS analysis were carried out using the lme and gls functions from the nlme package (Pinheiro and Bates, 2000), with the varIdent and the varConstPower constructor functions used to incorporate heterogeneity in residual variation into the model where needed. A backwards approach was used for model selection, starting with the global model which fully crossed all explanatory variables. Simpler models were then selected using a combination of Akaike information criteria (AICc) and hypothesis testing (likelihood ratio tests). Model selection was first applied to the random structure (variance heterogeneity and random effects, where applicable) using restricted maximum likelihood (REML) estimation, then to the fixed structure (fixed effects) using maximum likelihood (ML) estimation. Terms were removed from the model if the AICc decreased. When terms were removed and the AICc increased by more than two, the model with the lower AICc was selected, regardless of differences in complexity. In cases where dropping a term increased the AICc by less than two, likelihood ratio tests were used. When $p<0.05$, the model with the lower AICc was selected and the principle of parsimony was applied when $p>0.05$, and the model with the lower number of parameters was selected. When response variables were influenced by independent factors, Tukey post-hoc analysis was performed using the lsmeans package (Lenth, 2016). All Cellular Energy Allocation data was log-transformed to better meet assumptions of normality. 


\subsection{Field Measurements}

\subsubsection{Metabolic and Osmoregulatory responses}

No significant differences in rates of oxygen uptake were observed among the three

populations of $G$. setosus at the time of field capture $\left(\mathrm{F}_{(2,21)}=1.164, p=0.332\right.$; Figure 2$)$.

Likewise, there were no significant differences in coxal gill $\mathrm{Na}^{+} / \mathrm{K}^{+}$-ATPase activity $\left(\mathrm{F}_{(2,15)}=1.149, p=0.343\right)$ or haemolymph osmolality $\left(\mathrm{F}_{(2,21)}=2.191, p=0.137\right)$ among the three populations of G. setosus (Table 3).

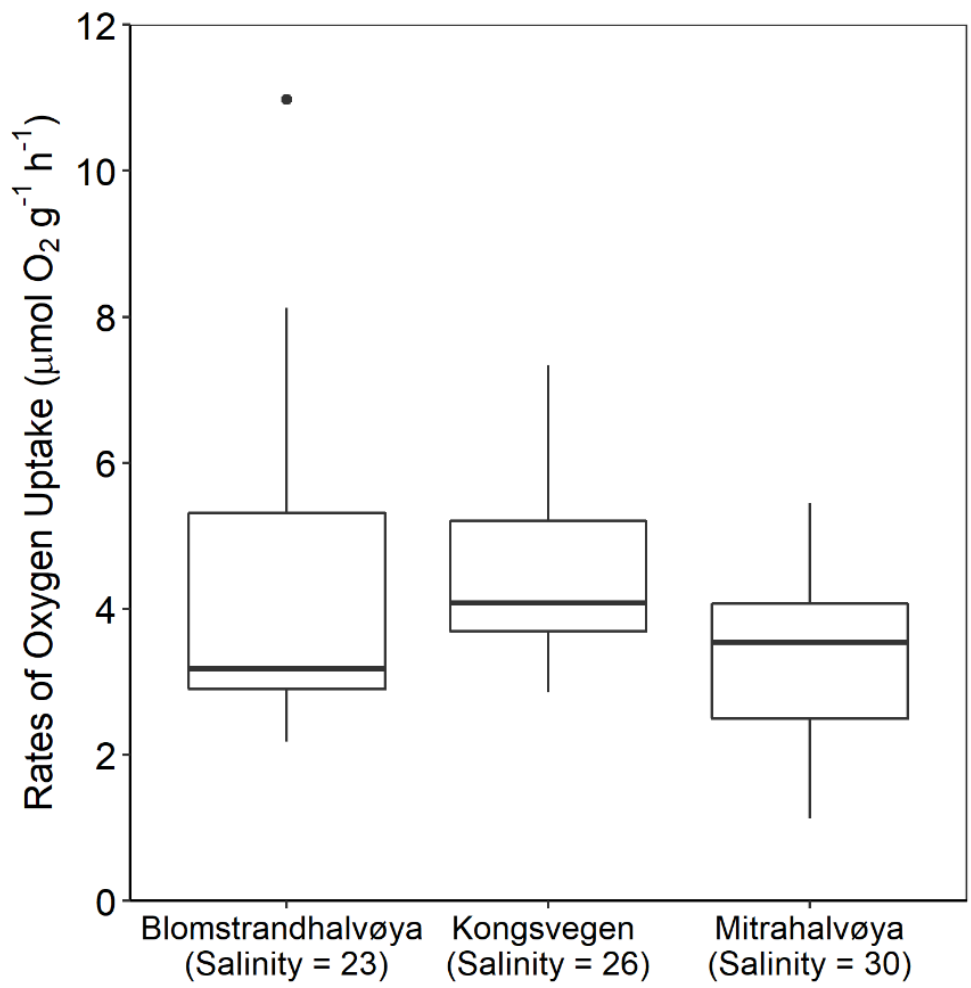




\begin{tabular}{cccr}
\hline Population & $\begin{array}{c}\text { Medium } \\
\text { Osmolality } \\
\left(\mathrm{mOsm} \mathrm{kg}^{-1}\right)\end{array}$ & $\begin{array}{c}\text { Haemolymph } \\
\text { Osmolality } \\
\left(\mathrm{mOsm} \mathrm{kg}^{-1}\right)\end{array}$ & $\begin{array}{c}\mathrm{Na}^{+} / \mathrm{K}^{+}-\mathrm{ATPase} \\
\mathrm{activity}(\mu \mathrm{mol} \mathrm{ADP} \\
\left.\mathrm{mg} \mathrm{Protein}^{-1} \mathrm{~h}^{-1}\right)\end{array}$ \\
\hline $\begin{array}{c}\text { Blomstrandhalvøya } \\
\text { (Lower-salinity) }\end{array}$ & $\begin{array}{c}685.6 \\
( \pm 14.79)\end{array}$ & $880.0( \pm 52.98)$ & $3.164( \pm 0.401)$ \\
$\begin{array}{c}\text { Kongsvegen } \\
\text { (Lower-salinity) }\end{array}$ & $\begin{array}{c}779.7 \\
( \pm 40.25)\end{array}$ & $842.4( \pm 41.70)$ & $3.181( \pm 0.221)$ \\
$\begin{array}{c}\text { Mitrahalvøya } \\
\text { (Higher-salinity) }\end{array}$ & $\begin{array}{c}928.0 \\
( \pm 13.20)\end{array}$ & $964.4( \pm 28.27)$ & $2.359( \pm 0.605)$ \\
\hline
\end{tabular}

359

360

361

362

363

364

365

366

367

Table 3. Osmolality ( $\mathrm{mOsm} \mathrm{kg} \mathrm{kg}^{-1}$ ) of the water samples from the three collection sites ( $\mathrm{n}=3$ for each site), and haemolymph osmolality and coxal gill $\mathrm{Na}^{+} / \mathrm{K}^{+}$-ATPase activity ( $\mu$ mol ADP mg Protein $\left.^{-1} \mathrm{~h}^{-1}\right)$ in the three populations of Gammarus setosus at the time of field capture $(\mathrm{n}=8$ for haemolymphs samples and $\mathrm{n}=6$ for $\mathrm{Na}^{+} / \mathrm{K}^{+}$-ATPase activity for each population). Values given as means with SEM in parenthesis.

\subsubsection{Cellular Energy Allocation}

Significant differences in CEA values were observed between the three populations of $G$. setosus $\left(\mathrm{F}_{(2,21)}=10.77, p=0.0001\right)$. CEA values were significantly higher in the higher-salinity Mitrahalvøya population than the lower-salinity Blomstrandhalvøya $(p=0.003)$ and Kongsvegen $(p=0.001)$ populations, with no significant differences between the two lowersalinity populations $(p=0.949$; Figure $3 a)$.

Significant differences in energy consumption $\left(E_{c}\right)$ were observed between the three populations of G. setosus $\left(\mathrm{F}_{(2,21)}=5.975, p=0.008\right)$. $\mathrm{E}_{\mathrm{c}}$ was significantly lower in the highersalinity population from Mitrahalvøya than the lower-salinity populations from Blomstrandhalvøya $(p=0.013)$ and Kongsvegen $(p=0.027)$, which showed no significant difference ( $p=0.945$; Figure $3 b)$. Likewise, significant differences in the energy available $\left(\mathrm{E}_{\mathrm{a}}\right)$ were observed between the three populations of $G$. setosus $\left(\mathrm{F}_{(2,21)}=4.457, p=0.024\right)$. $\mathrm{E}_{\mathrm{a}}$ was significantly higher in the higher-salinity Mitrahalvøya population than the lower-salinity Kongsvegen $(p=0.024)$ population. No significant differences were observed between the 
higher-salinity Mitrahalvøya population and the other lower-salinity Blomstrandhalvøya population ( $p=0.099)$, or between the two lower-salinity populations $(p=0.776$; Figure $3 \mathrm{c})$.
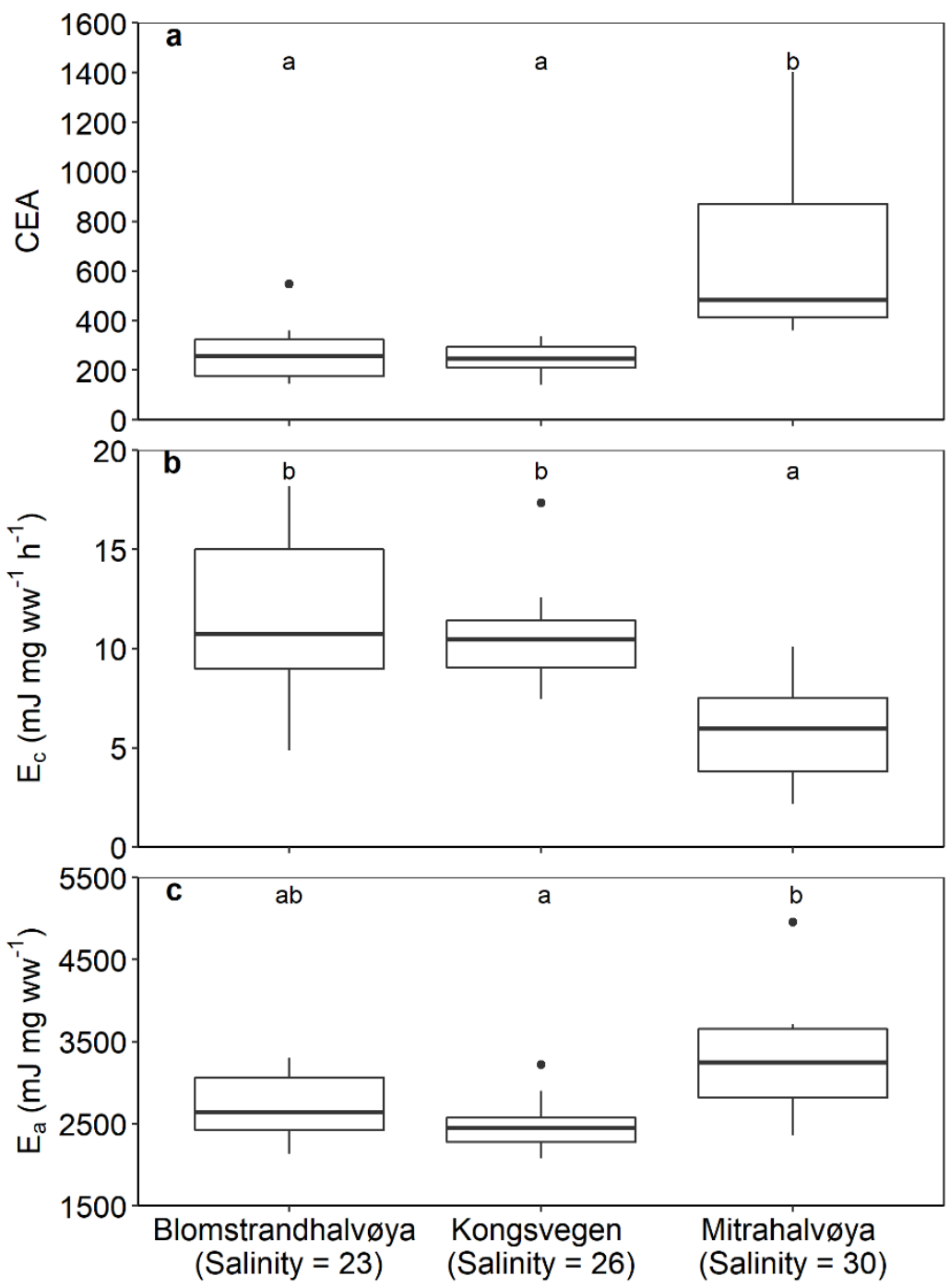

Figure 3. Cellular Energy Allocation (CEA) (a), energy consumption (Ec; mJ mg ww ${ }^{-1} \mathrm{~h}^{-1}$ ) (b) and available energy $\left(\mathrm{E}_{\mathrm{a}} ; \mathrm{mJ} \mathrm{mg} \mathrm{ww}^{-1}\right)$ (c) in two lower-salinity populations (Blomstrandhalvøya and Kongsvegen) and one higher-salinity population (Mitrahalvøya) of Gammarus setosus at the time of field capture. $\mathrm{n}=8$ for each population. The plots show the median (line inside the box), the 25th and 75th percentiles (extent of boxes), maximum and minimum values within the $1.5 x$ interquartile range (whiskers) and outliers (closed circle), exceeding the $1.5 x$ interquartile range. Different letters indicate significant differences between treatments (ANOVA, Tukey HSD post hoc, $\mathrm{p}<0.05$ ).

The differences in $E_{a}$ among the populations reflects the variations in energy content associated with total protein and carbohydrate levels. Significant differences in the carbohydrate energy reserves were observed among the three populations of G. setosus 
$410\left(\mathrm{~F}_{(2,21)}=5.226, p=0.014\right)$. Carbohydrate energy reserves were significantly higher in the higher-

411 salinity Mitrahalvøya population than the lower-salinity Blomstrandhalvøya $(p=0.018)$ and

412 Kongsvegen $(p=0.046)$ populations, which were not significantly different from each other

413 ( $p=0.900 ;$ Table 4). Significant differences in the protein energy reserves were also observed

414 between the three populations of $G$. setosus $\left(\mathrm{F}_{(2,21)}=3.561, p=0.047\right)$, as protein energy reserves

were significantly higher in the higher-salinity Mitrahalvøya population than the lower-salinity

Kongsvegen $(p=0.037)$ population. No significant differences in protein energy reserves were

observed between the higher-salinity Mitrahalvøya population and the other lower-salinity

Blomstrandhalvøya population $(p=0.421)$, or between the two lower-salinity populations

( $p=0.365$; Table 4). No significant differences in the lipid energy reserves were observed

among the three populations of $G$. setosus $\left(\mathrm{F}_{(2,21)}=1.889, p=0.176\right.$; Table 4).

\begin{tabular}{|c|c|c|c|}
\hline Population & $\begin{array}{c}\text { Protein } \\
\left.(\mathrm{mJ} \mathrm{mg} \mathrm{ww})^{-1}\right)\end{array}$ & $\begin{array}{c}\text { Lipid } \\
\left.(\mathrm{mJ} \mathrm{mg} \mathrm{Ww})^{-1}\right)\end{array}$ & $\begin{array}{l}\text { Carbohydrate } \\
\left(\mathrm{mJ} \mathrm{mg} \mathrm{ww}^{-1}\right)\end{array}$ \\
\hline Blomstrandhalvøya (Salinity = 23) & $1350( \pm 64.25)^{\mathrm{b}}$ & $1308( \pm 192.5)$ & $48.41( \pm 12.00)^{\mathrm{a}}$ \\
\hline Kongsvegen (Salinity = 26) & $1185( \pm 80.44)^{\mathrm{a}}$ & $1264( \pm 160.2)$ & $55.34( \pm 13.35)^{\mathrm{ab}}$ \\
\hline Mitrahalvøya $($ Salinity $=30)$ & $1502( \pm 102.53)^{\mathrm{c}}$ & $1751( \pm 229.2)$ & $95.86( \pm 7.21)^{\mathrm{b}}$ \\
\hline
\end{tabular}

421

422

423

424

425

426

427

Table 4. Lipid, protein and carbohydrate energy equivalents $\left(\mathrm{mJ} \mathrm{mg} \mathrm{ww}^{-1}\right)$ in three populations of Gammarus setosus at the time of field capture. $\mathrm{n}=8$ for each population. Values given as means with SEM in parenthesis. Different letters indicate significant differences between treatments.

\subsection{Laboratory Experiments}

\subsubsection{Metabolic responses}

Oxygen uptake rates measured after laboratory exposure experiments were influenced by an interaction between salinity and population, as well as by $p \mathrm{CO}_{2}$ (Figure $4, \mathrm{~S} 1$ and S2). Low salinity significantly increased oxygen uptake rates in individuals from the higher-salinity Mitrahalvøya population $(p=0.0023)$, but not in individuals from the lower-salinity Kongsvegen $(p=1.000)$ or Blomstrandhalvøya $(p=0.229)$ populations. Oxygen uptake rates 

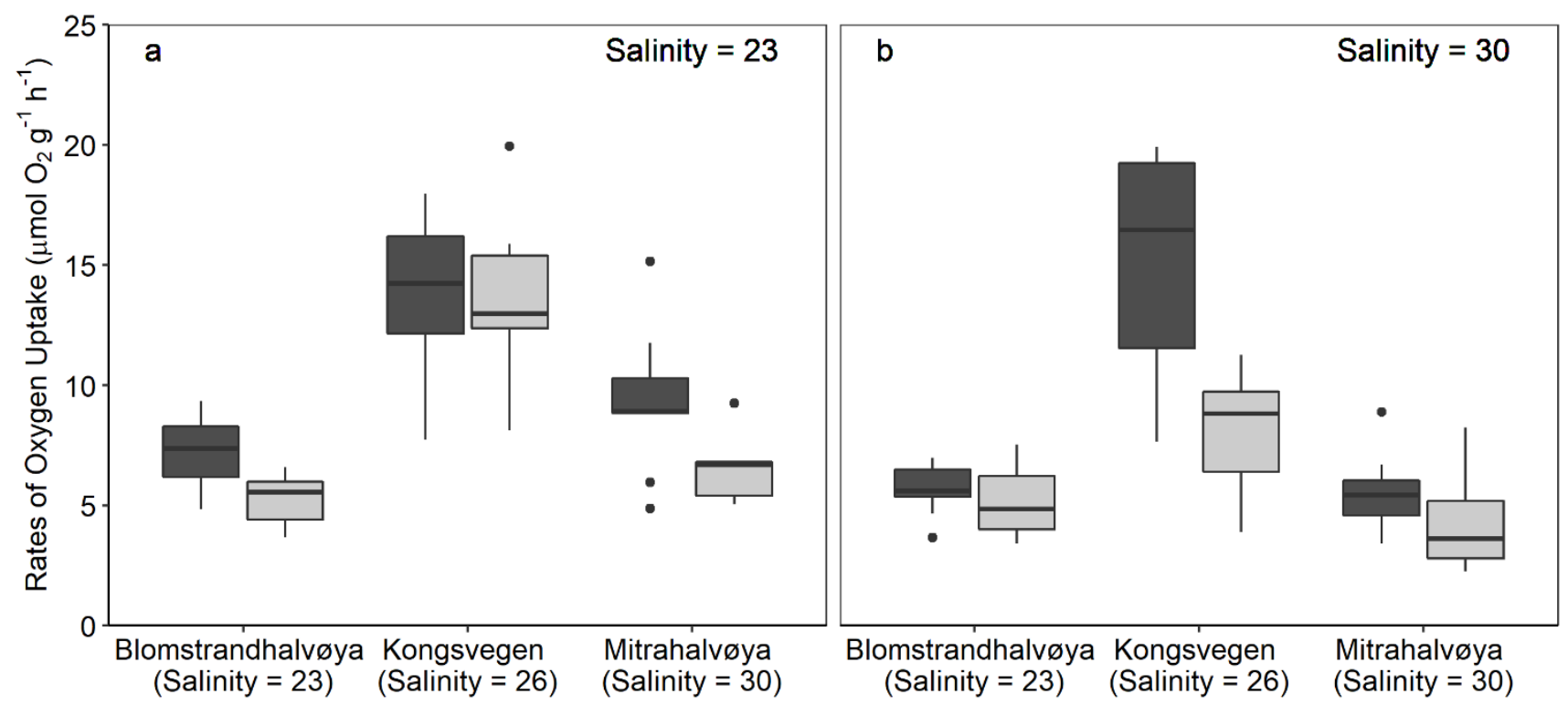

Figure 4. Oxygen uptake rates $\left(\mu \mathrm{mol} \mathrm{O}_{2} \mathrm{~g}^{-1} \mathrm{~h}^{-1}\right.$ ) in two lower-salinity populations (Blomstrandhalvøya and Kongsvegen) and one higher-salinity population (Mitrahalvøya) of Gammarus setosus after 28 days exposure to a salinity of 23 (a) or 30 (b) and/or ambient (400 $\mu$ atm; black bars) or elevated (1000 $\mu \mathrm{atm}$; grey bars) $p \mathrm{CO}_{2} . \mathrm{n}=9$ for each treatment except for Mitrahalvøya $\left(\mathrm{S}=23 /\right.$ elevated $\left.p \mathrm{CO}_{2}\right)$, Blomstrandhalvøya $\left(\mathrm{S}=30 /\right.$ elevated $\left.p \mathrm{CO}_{2}\right)$ and Kongsvegen ( $\mathrm{S}=30 /$ ambient $p \mathrm{CO}_{2}, \mathrm{~S}=23 /$ ambient $p \mathrm{CO}_{2}$, and $\mathrm{S}=30 /$ elevated $p \mathrm{CO}_{2}$ ), where $\mathrm{n}=8$. The plots show the median (line inside the box), the 25th and 75th percentiles (extent of boxes), maximum and minimum values within the $1.5 \mathrm{x}$ interquartile range (whiskers) and outliers (closed circle), exceeding the $1.5 x$ interquartile range.

After laboratory exposure experiments, only salinity had a significant effect on coxal gill

$\mathrm{Na}^{+} / \mathrm{K}^{+}$-ATPase (Tables $\mathrm{S} 1$ and $\mathrm{S} 2$ ), with activity levels around 1.5 times higher at a salinity salinity, $p \mathrm{CO}_{2}$ and population (Tables 5, S1 and S2). Haemolymph osmolality was around 165 mOsm kg ${ }^{-1}$ higher in individuals held at salinity 30, compared with individuals held at salinity 23, and around $30 \mathrm{mOsm} \mathrm{kg}{ }^{-1}$ higher in individuals held at elevated $p \mathrm{CO}_{2}$, compared with individuals held at ambient $p \mathrm{CO}_{2}$. Across all treatments, individuals from the lowest-salinity 
Blomstrandhalvøya population had significantly higher haemolymph osmolality than individuals from the Mitrahalvøya population Kongsvegen population ( $p=0.538)$.
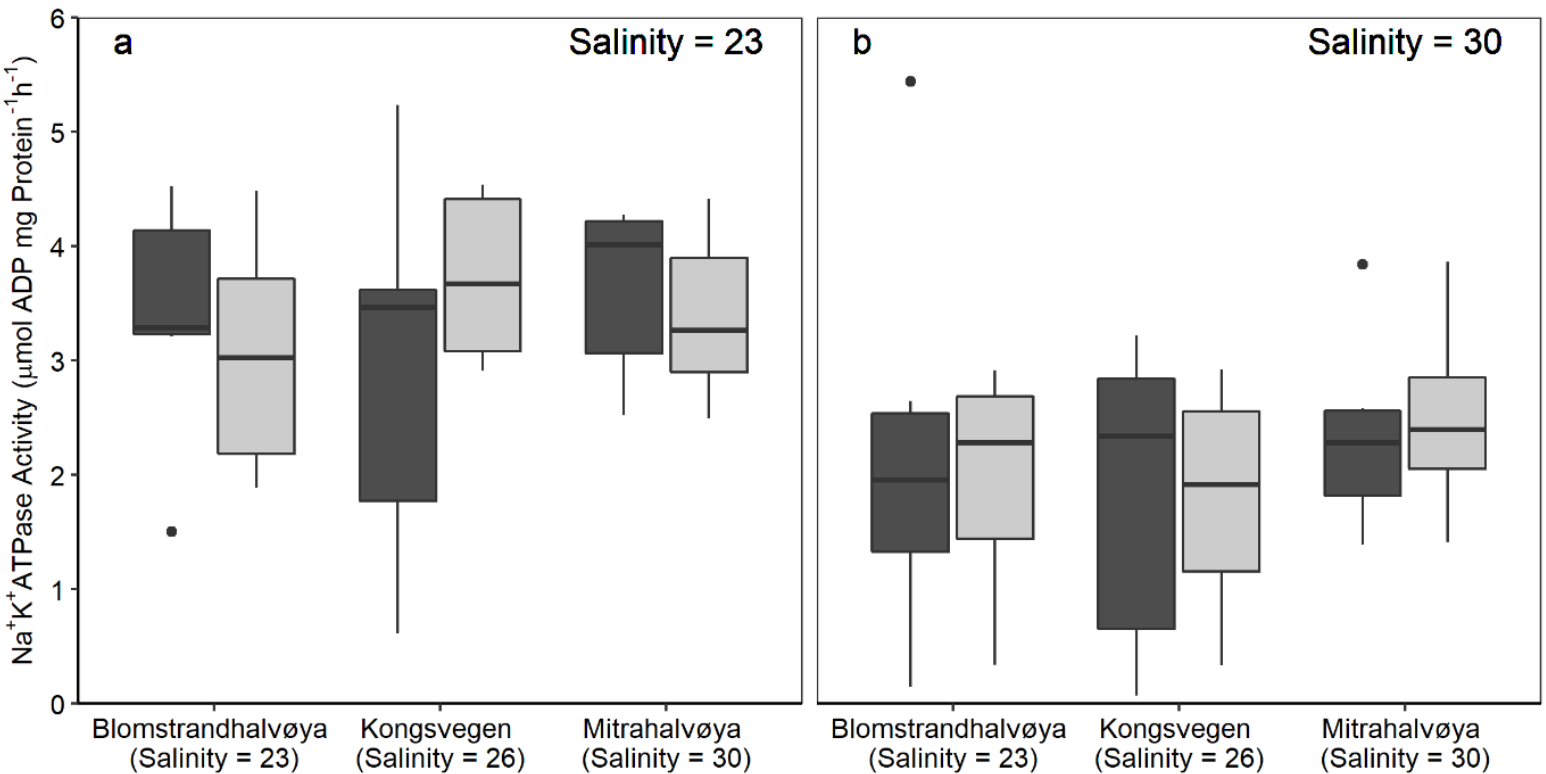

Figure 5. $\mathrm{Na}^{+} / \mathrm{K}^{+}$-ATPase activity ( $\mu \mathrm{mol}$ ADP $\mathrm{mg}$ Protein ${ }^{-1} \mathrm{~h}^{-1}$ ) in two lower-salinity populations (Blomstrandhalvøya and Kongsvegen) and one higher-salinity population (Mitrahalvøya) of Gammarus setosus after 28 days exposure to a salinity of 23 (a) or 30 (b) and/or ambient ( $400 \mu \mathrm{atm}$; black bars) or elevated (1000 $\mu$ atm; grey bars) $p \mathrm{CO}_{2}(\mathrm{n}=6$ for each treatment). The plots show the median (line inside the box), the 25th and 75th percentiles (extent of boxes), maximum and minimum values within the $1.5 x$ interquartile range (whiskers) and outliers (closed circle), exceeding the $1.5 x$ interquartile range.

\begin{tabular}{ccccc}
\hline Population & Salinity & $p \mathrm{CO}_{2}$ & $\begin{array}{c}\text { Medium Osmolality } \\
\left(\mathrm{mOsm} \mathrm{kg}^{-1}\right)\end{array}$ & $\begin{array}{c}\text { Haemolymph } \\
\text { Osmolality } \\
\left(\mathrm{mOsm} \mathrm{kg}^{-1}\right)\end{array}$ \\
\hline $\begin{array}{c}\text { Blomstrandhalvøya } \\
\text { (Lower-salinity) }\end{array}$ & 30 & Ambient & $931.2(6.676)$ & $983.2(10.94)$ \\
& 23 & Elevated & $940.7(10.13)$ & $992.8(96.97)$ \\
& 23 & Embient & $641.3(9.493)$ & $800.8(22.38)$ \\
Kongsvegen & 30 & Ambient & $653.8(6.85)$ & $811.5(61.53)$ \\
(Lower-salinity) & 30 & Elevated & $934.8(6.797)$ & $915.3(17.35)$ \\
& 23 & Ambient & $648.8(10.129)$ & $701.3(19.05)$ \\
& 23 & Elevated & $653.3(9.074)$ & $721.0(30.94)$ \\
\hline Mitrahalvøya & 30 & Ambient & $920.0(7.578)$ & $841.5(28.47)$ \\
(Higher-salinity) & 30 & Elevated & $927.7(9.477)$ & $897.8(28.12)$ \\
\hline
\end{tabular}




\begin{tabular}{cccc}
\hline 23 & Ambient & $645.3(8.257)$ & $697.5(11.5)$ \\
23 & Elevated & $646.33(7.745)$ & $744.8(12.20)$ \\
\hline
\end{tabular}

Table 5. Osmolality $\left(\mathrm{mOsm} \mathrm{kg}^{-1}\right)$ of the water samples from each treatment and haemolymph in the three populations of Gammarus setosus after 28 days exposure to a salinity of 23 or 30 and/or ambient $(400 \mu \mathrm{atm})$ or elevated $(1000 \mu \mathrm{atm}) p \mathrm{CO}_{2} . \mathrm{n}=6$ for each treatment. Values given as means with SEM in parenthesis.

\subsubsection{Cellular energy allocation}

Salinity was the only factor to significantly affect CEA (Tables S1 and S2) with CEA values 5.2 times higher in amphipods held at salinity 30 compared with those held at salinity 23 (Figure 6a). Energy consumption $\left(E_{c}\right)$ and energy available $\left(E_{a}\right)$ varied according to population and salinity (Figure 6b,c; Tables S1 and S2). $\mathrm{E}_{\mathrm{c}}$ was 2.3 times higher in amphipods held at salinity 23 compared with amphipods held at salinity 30. Individuals from the lower-salinity Kongsvegen population had significantly lower $\mathrm{E}_{\mathrm{c}}$ than individuals from the higher-salinity Mitrahalvøya population $(p=0.012)$. There were no significant differences in $\mathrm{E}_{\mathrm{c}}$ between individuals from the two lower-salinity Blomstrandhalvøya and Kongsvegen populations $(p=0.225)$ or between individuals from the lower-salinity Blomstrandhalvøya and the highsalinity Mitrahalvøya population ( $p=0.322) . \mathrm{E}_{\mathrm{a}}$ was 1.3 times higher in amphipods held at salinity 30 compared with amphipods held at salinity 23 . Individuals from the lower-salinity Kongsvegen population had significantly lower $E_{a}$ than individuals from the higher-salinity Mitrahalvøya population $(p<0.001)$ and the other lower-salinity Blomstrandhalvøya population $(p<0.001)$, which were not significantly different $(p=0.996)$. 

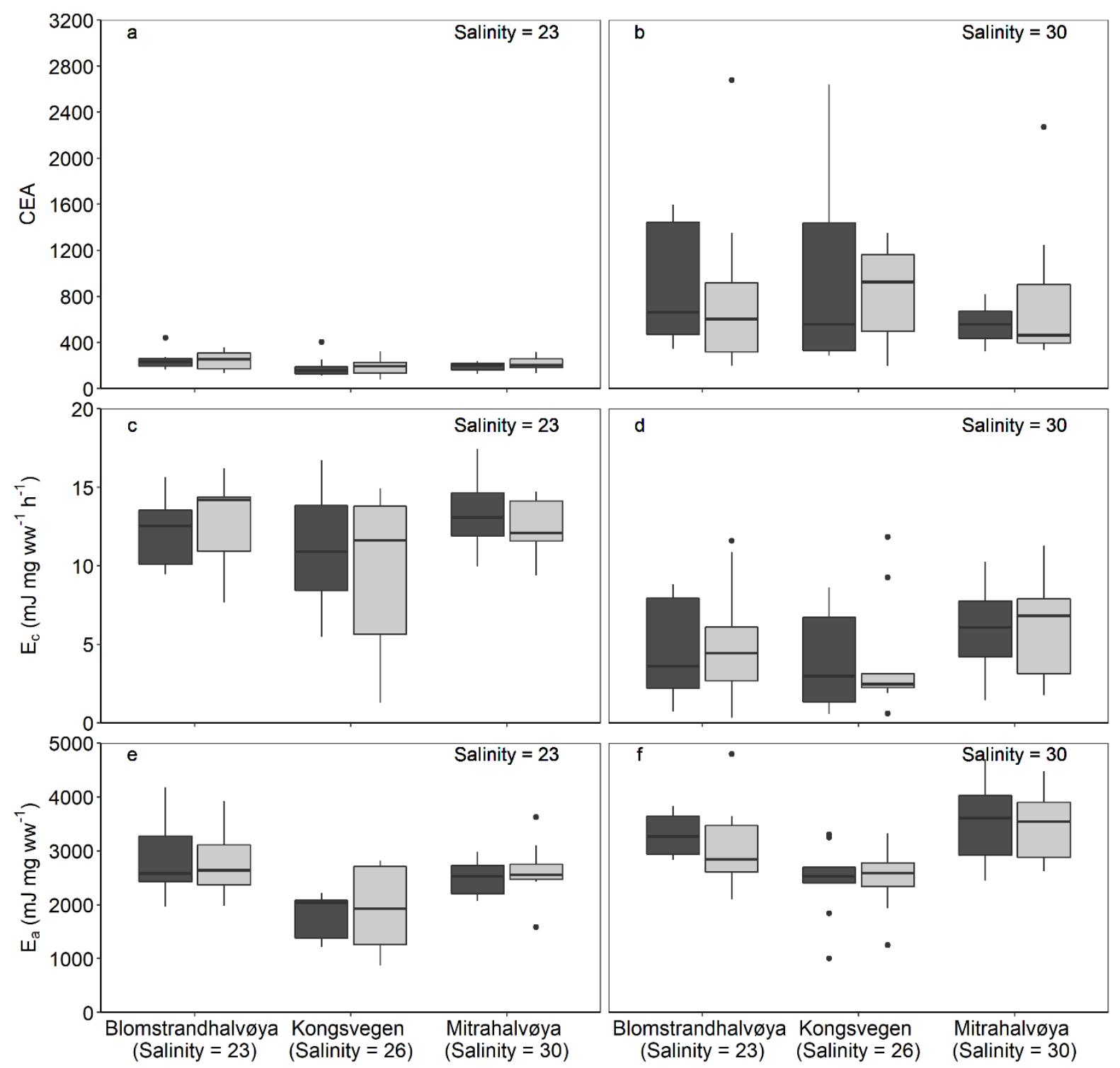

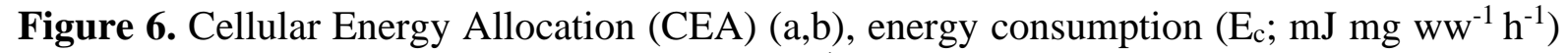
$(\mathrm{c}, \mathrm{d})$ and available energy $\left(\mathrm{E}_{\mathrm{a}} ; \mathrm{mJ} \mathrm{mg} \mathrm{ww}^{-1}\right)(\mathrm{e}, \mathrm{f})$ in two lower-salinity populations (Blomstrandhalvøya and Kongsvegen) and one higher-salinity population (Mitrahalvøya) of Gammarus setosus. Amphipods exposed for 28 days to a salinity of 23 (a, c, and e), or 30 (b, $\mathrm{d}$, and $\mathrm{f})$. Within each panel, values are given for exposure to ambient $p \mathrm{CO}_{2}(400 \mu \mathrm{atm}$; black bars) or elevated $p \mathrm{CO}_{2}(1000 \mu \mathrm{atm}$; grey bars $) . \mathrm{n}=9$ for each treatment. The plots show the median (line inside the box), the 25th and 75th percentiles (extent of boxes), maximum and minimum values within the $1.5 \mathrm{x}$ interquartile range (whiskers) and outliers (closed circle), exceeding the $1.5 x$ interquartile range. 
23. Amphipods from the lower-salinity Kongsvegen population had significantly lower lipid and protein energy reserves than individuals from the other lower-salinity Blomstrandhalvøya population (protein: $p=0.0004$; lipid: $p<0.001$ ) and the higher-salinity Mitrahalvøya population (protein: $p=0.002$; lipid: $p<0.001$ ). No significant differences were observed in lipid and protein energy reserves between individuals from the lower-salinity Blomstrandhalvøya and higher-salinity Mitrahalvøya populations (protein: $p=0.535$; lipid: $p=0.958$ ).

\begin{tabular}{cccccc}
\hline Population & Salinity & $p \mathrm{CO}_{2}$ & $\begin{array}{c}\text { Protein } \\
\left(\mathrm{mJ} \mathrm{mg} \mathrm{ww}^{-1}\right)\end{array}$ & $\begin{array}{c}\text { Lipid } \\
\left(\mathrm{mJ} \mathrm{mg} \mathrm{ww}^{-1}\right)\end{array}$ & $\begin{array}{c}\text { Carbohydrate } \\
\left(\mathrm{mJ} \mathrm{mg} \mathrm{ww}^{-1}\right)\end{array}$ \\
\hline $\begin{array}{c}\text { Blomstrandhalvøya } \\
\text { (Lower-salinity) }\end{array}$ & 30 & Ambient & $1516(98.63)$ & $1661(148.5)$ & $104.8(13.36)$ \\
& 23 & Elevated & $1440(196.2)$ & $1547(212.4)$ & $102.5(12.75)$ \\
& 23 & Embient & $1423(76.09)$ & $1394(177.8)$ & $56.80(8.774)$ \\
\hline Kongsvegen & 30 & Ambient & $1282(110.5)$ & $1077(162.0)$ & $89.45(7.558)$ \\
(Lower-salinity) & 30 & Elevated & $1361(78.48)$ & $1018(185.9)$ & $97.87(8.266)$ \\
& 23 & Ambient & $960.5(140.8)$ & $746.8(111.1)$ & $58.63(9.995)$ \\
& 23 & Elevated & $1080(136.8)$ & $788.5(178.6)$ & $62.70(13.40)$ \\
\hline Mitrahalvøya & 30 & Ambient & $1637(63.47)$ & $1796(239.8)$ & $102.4(9.196)$ \\
(Higher-salinity) & 30 & Elevated & $1575(152.2)$ & $1820(156.8)$ & $99.72(13.88)$ \\
& 23 & Ambient & $1233(74.78)$ & $1215(136.5)$ & $44.78(6.852)$ \\
& 23 & Elevated & $1222(68.51)$ & $1336(201.0)$ & $61.94(7.842)$ \\
\hline
\end{tabular}

Table 6. Lipid, protein and carbohydrate energy equivalents $\left(\mathrm{mJ} \mathrm{mg} \mathrm{ww}^{-1}\right)$ in three populations of Gammarus setosus after 28 days exposure to the four salinity/ $\mathrm{CO}_{2}$ combinations: Salinity of either 23 or 30; $p \mathrm{CO}_{2}$ of either ambient, $400 \mu \mathrm{atm}$, or elevated $p \mathrm{CO}_{2}, 1000 \mu \mathrm{atm} . \mathrm{n}=9$ for each treatment. Values given as means with SEM in parenthesis.

\section{Discussion}

Summer field sampling revealed that populations of the circumpolar arctic/subarctic amphipod G. setosus inhabiting a salinity gradient in the Kongsfjorden-Krossfjorden region of western Svalbard had similar levels of coxal $\mathrm{Na}^{+} / \mathrm{K}^{+}$-ATPase activities and haemolymph osmolality, suggesting no differences in osmoregulatory capacity. Cellular energy budgets, however, were lower in the two populations living within Kongsfjorden and experiencing lower salinity. Amphipods from these populations had higher levels of cellular energy consumption $\left(\mathrm{E}_{\mathrm{c}}\right)$ and 
lower cellular energy reserves $\left(\mathrm{E}_{\mathrm{a}}\right)$, but similar whole-organism rates of oxygen uptake. In the laboratory, low salinity had a similar effect across all populations, with reductions in CEA coinciding with higher $\mathrm{Na}^{+} / \mathrm{K}^{+}$ATPase activities and higher $\mathrm{E}_{\mathrm{c}}$. Low salinity exposer also resulted in elevated whole-organism metabolic costs (indicated by higher rates of oxygen uptake) but only in amphipods from Mitrahalvøya that are not naturally exposed to the same low salinities as amphipods from the other sites. An elevation in $p \mathrm{CO}_{2}$ in the laboratory had no effect on $\mathrm{Na}^{+} / \mathrm{K}^{+}$ATPase activities, or on CEA, but it did increase haemolymph osmolality, and resulted in lower rates of oxygen uptake in amphipods from all populations. Unlike previous studies, there were no interactions between $p \mathrm{CO}_{2}$ and salinity (Rastrick et al., 2018a; Whiteley et al., 2018). The relevance of the independent effects of salinity and $p \mathrm{CO}_{2}$ on amphipod osmoregulatory capacity and the likely repercussions on energy budgets and fitness is discussed below.

\subsection{Effects of salinity}

The similarity in coxal gill $\mathrm{Na}^{+} / \mathrm{K}^{+}$ATPase activities among the three populations of $G$. setosus in the field plus the similarity in response to low salinity in the laboratory, suggests a lack of diversity in osmoregulatory capacities, despite differences in salinity exposures in the natural environment. The values for $\mathrm{Na}^{+} / \mathrm{K}^{+}$ATPase activities in the field compared favourably with the values obtained from amphipods acclimated to low salinity for one month in the laboratory

$541(\mathrm{~S}=23)$, and were noticeably higher than the amphipods acclimated to full strength seawater $(\mathrm{S}=30)$. Active ion uptake is well known to increase in osmoregulating crustaceans in response to low salinity exposure taking on average 7 hours to increase and remaining elevated for as long as the exposures last, even up to 12 months (Henry et al., 2012; Whiteley et al., 2018). It appears that $G$. setosus showed the same response under controlled conditions, indicating that they rely on ion exchange processes driven by increasing $\mathrm{Na}^{+} / \mathrm{K}^{+}$-ATPase activities under low salinity, just like other strong osmoregulators, including other gammarid species (Brooks and 
Mills, 2006; Henry et al., 2012). The pattern of haemolymph osmolality reflects that of a strong hyper-iso-osmoregulator i.e. haemolymph isosmotic with the external medium in the high salinity treatment, but hyperosmotic to the external medium in the low salinity treatment (Henry et al., 2012). This is not surprising that G. setosus is a strong hyper-isoosmoregulator as it occurs in estuaries and upper tidal pools in northern areas and can survive in the surface melt water of northern seas (Steele and Steele, 1970; Ingólfsson, 1977). The relatively high $\mathrm{Na}^{+} / \mathrm{K}^{+}$-ATPase activities observed in amphipods from the higher-salinity Mitrahalvøya population indicate that they maybe exposed to occasional bouts of low salinity, despite average salinities being higher than at the other sites.

Regardless of the similarity in active ion uptake across the populations in the field, energy budgets differed due to higher $\mathrm{E}_{\mathrm{c}}$ and lower $\mathrm{E}_{\mathrm{a}}$ values in the lower-salinity populations. Elevations in $E_{c}$ signify an increase in energy expenditure, which are likely to result from relatively high $\mathrm{Na}^{+} / \mathrm{K}^{+}$-ATPase activities, as this ion transporting pump is energetically demanding being estimated to consume between 11 and $21 \%$ of total oxygen uptake in the freshwater gammarid amphipod Gammarus pulex (Sutcliffe, 1984). However, the similarity in $\mathrm{Na}^{+} / \mathrm{K}^{+}$-ATPase activities across all populations, suggests that other osmoregulatory adjustments may also occur in the low salinity populations to account for reductions in $\mathrm{E}_{\mathrm{c}}$. This could include the mobilisation of osmotically active solutes, such as amino acids, which are estimated to consume around $12 \%$ of daily energy use in the intertidal copepod (Goolish and

567 Burton, 1989). Reductions in surface permeability may also play a role in the longer-term, although this response is considered less energetically demanding than increases in active ion uptake (Rivera-Ingraham and Lignot, 2017), but has been reported previously in G. setosus and other species of gammarid amphipod (Lockwood and Inman, 1973; Bolt, 1983). The small

571 differences in $E_{a}$ between the lower-salinity Kongsvegen population and the higher-salinity

572 Mitrahalvøya population in the field were primarily driven by reductions in total protein energy 
reserves. This observation suggests that $G$. setosus metabolises proteins during increased $\mathrm{E}_{\mathfrak{c}}$, similar to Callinectes danae (Ramaglia et al., 2018). However, total carbohydrate and protein energy reserves could also be influenced by other factors, such as feeding rates, growth, diet, moult stage, stage of the life cycle etc (Fraser and Rogers, 2007; Jimenez and Kinsey, 2015). As these amphipods were studied in the field and their growth and nutritional history remains unknown, these relationships require further investigation.

Acclimation studies confirmed that low salinity was responsible for increasing $\mathrm{E}_{\mathrm{c}}$ and reducing $\mathrm{E}_{\mathrm{a}}$ in all 3 populations of $G$. setosus, regardless of habitat salinity. The increase in $\mathrm{E}_{\mathrm{c}}$ at low salinity coincided with an increase in coxal gill $\mathrm{Na}^{+} / \mathrm{K}^{+}$-ATPase activities demonstrating the importance of energy demanding enzymes in maintaining haemolymph osmolality, and hence physiological homeostasis, in the face of salinity change in G. setosus. Low-salinity increases in $E_{c}$, however, were not matched by an associated increase in whole-organism rates of oxygen uptake, unlike previous studies where metabolic rates in gammarid amphipods increased under low salinity (e.g. Dorgelo, 1973; Normant et al., 2004; Normant and Lamprecht, 2006). Such studies, however, involved exposures to lower salinities for shorter periods ( $\leq 1$ week), suggesting that the amphipods were not fully acclimated to the new salinity, and metabolic adjustments were still taking place. The increase in energy expenditure at the cellular level at constant rates of whole-organism oxygen uptake suggest an increase in mitochondrial efficiency, and hence the capacity to generate ATP. There is an increasing realisation that mitochondrial efficiencies, taken as the amount of ATP generated per unit of oxygen consumed, are plastic and can vary between tissues, individuals and species, as well as in response to environmental change (reviewed by Salin et al., 2015). Although much of the information about environmental effects come from studies on temperature and starvation, increases in mitochondrial efficiency would benefit amphipods experiencing prolonged exposure to low salinity in their natural environments. As salinity had no effect on whole- 
organism rates of oxygen uptake, it is also possible that energy was reallocated to

599

600

601

602

603

604

605

606

607

608

609

610

611

612

613

614

615

616

617

618

619

620

621

622

osmoregulation from other ATP demanding processes, such as growth and reproduction, as described under acidified conditions in juvenile European lobsters, Homarus gammarus (Small et al., 2020), and larval sea urchins, Strongylocentrotus purpuratus (Pan et al., 2015). However, trade-offs at the cellular level seem unlikely because of the increase in $\mathrm{E}_{\mathrm{c}}$ at low salinity. Interestingly, low salinity acclimation increased oxygen uptake rates in the higher-salinity population from Mitrahalvøya. Amphipods from this population may be more sensitive to the salinity change, probably because biochemical adjustments in mitochondrial efficiency were less marked, and/or energy reallocation at the whole-organism level was less likely. Regardless, the increase in metabolic rate indicates increased demand for ATP at the whole animal level leading to increased food requirements.

The decrease in $\mathrm{E}_{\mathrm{a}}$ during low salinity exposure occurred primarily due to lower total protein and lipid energy reserves. However, it is interesting to note that energy reserves were higher in amphipods held in the laboratory at both salinities and under ambient $\mathrm{CO}_{2}$, than the values measured at their respective salinities in the field. It is likely that amphipods held in the laboratory and receiving food on a regular basis, were better fed than the field amphipods and hence were better able to maintain their energy reserves against increased energy expenditure. The decline in $\mathrm{E}_{\mathrm{a}}$ may also indicate changes in the turnover of protein and lipids due to tradeoffs with the energy requirements for osmoregulation. For instance, protein turnover (protein synthesis vs degradation) is an important determinant of growth, and is an energetically costly process, consuming between 11 and $42 \%$ of resting oxygen uptake (Houlihan et al., 1995) and accounts for $28 \%$ of oxygen uptake in the closely related amphipod Gammarus oceanicus from Kongsfjorden (Rastrick and Whiteley, 2017). Moreover, salinity is known to influence wholeorganism protein synthesis rates, as demonstrated in juvenile freshwater prawns (Macrobrachium rosenbergii) where exposure to freshwater resulted in increased gill $\mathrm{Na}^{+} / \mathrm{K}^{+}-$ 
623 ATPase activities, but a decline in protein synthesis rates, suggesting a reallocation of energy 624 to ion regulation (Intanai et al., 2009). As proteins and lipids are key for growth and

625

626

627

628

629

630

631

632

633

634

635

636

637

638

639

640

641

642

643

644

645

646 reproduction (D'Abramo et al., 1997), the reduction in both reserves in low salinity is likely to negatively impact both of these important ecological processes.

\subsection{Effect of elevated $\mathrm{CO}_{2}$}

Elevated $p \mathrm{CO}_{2}$ had no effect on active ion uptake in amphipods held in the laboratory, as reported in the shore crab, Carcinus meanas (Whiteley et al., 2018), and also the European lobster, H. gammarus (Small et al., 2020). Collectively, these observations suggest that this energy demanding enzyme is unlikely to contribute to the costs associated with haemolymph acid-base regulation during exposure to elevated $\mathrm{CO}_{2}$ (Whiteley, 2011; Small et al., 2020). In contrast, the laboratory experiments revealed that elevated $\mathrm{pCO}_{2}$ increased haemolymph osmolality in all three populations. This response is likely to be associated with the various ion transporting mechanisms responsible for both acid base and ion regulation in crustacean gills (reviewed by Whiteley, 2011). It is also possible that the external elevation in $p \mathrm{CO}_{2}$ led to amino acid catabolism and increased ammonia excretion which is also reported to buffer haemolymph $\mathrm{pH}$ under high $\mathrm{CO}_{2}$ (Fehsenfeld and Weihrauch, 2016). Such a response was observed in C. maenas where exposure to elevated $\mathrm{CO}_{2}$ reduced intracellular osmolytes similar to the changes expected from low salinity exposure (Hammer et al., 2012). It is possible that adjustments in small organic osmolytes are a common high $\mathrm{CO}_{2}$ response in aquatic crustaceans.

The lack of effect of $p \mathrm{CO}_{2}$ on the cellular energy budget and its components, further demonstrates that the energetic costs associated with maintaining acid-base status in G. setosus over one month were insignificant at the cellular level. This is in contrast to the situation in juvenile lobsters (Homarus americanus) where an increase in ETS activity was attributed to 
the maintenance of physiological homeostasis i.e. acid-base balance and calcification rates, both of which use ATP demanding ion pumps (Menu-Courey et al., 2019). Elevated $p \mathrm{CO}_{2}$ also resulted in lower rates of whole-organism oxygen uptake rates in amphipods from all populations. Another gammarid amphipod Gammarus locusta showed a similar response at $p \mathrm{CO}_{2}$ levels of 800-900 $\mu$ atm (Borges, 2018). Metabolic depression represents a short-term survival strategy to protect energy reserves under stressful conditions which is thought to be a characteristic of species more sensitive to elevated $\mathrm{CO}_{2}$, such as polar species (Kelley and Lunden, 2017). Polar species, such as G. setosus, are also characterised by lower aerobic scopes and limited capacities to increase metabolic rates with, for example, increases in environmental temperature (Rastrick and Whiteley 2011). Perhaps reductions in metabolic rate may be maintained more permanently in circumpolar environments, due to more stable, low temperature (i.e kinetic) conditions. However further longer-term studies are required to appreciate whether the lower metabolic rates observed here are transitory, or more permanent. For instance, both the deep-water, northern prawn Pandalus borealis and the hermit crab Pagurus tanneri can compensate metabolic rates over time under high $\mathrm{CO}_{2}$ (Kelley and Lunden, 2017). Changes in mitochondrial efficiency have also been observed under elevated $\mathrm{CO}_{2}$ over time as suggested in intertidal mussels Mytilus edulis and M. arenaria, and clams Mercenaria mercenaria, but this remains to be investigated in G. setosus (Sokolova, 2018).

\section{Conclusion}

In the field, populations of the circumpolar arctic/subarctic gammarid amphipod G. setosus inhabiting sites with different salinities, showed no differences in ion-transporting capacity, but lower-salinity populations had lower energy budgets than the higher-salinity population. In the laboratory, reduced salinity decreased energy budgets in amphipods from all 3 populations, but metabolic rates increased in amphipods from the higher-salinity population at Mitrahalvøya 
indicating sensitivity to salinity change. Elevated $\mathrm{CO}_{2}$ did not interact with salinity and had little effect on ion-transporting capacities, but increased haemolymph osmolality. Rates of oxygen uptake decreased under elevated $\mathrm{CO}_{2}$, which probably helped to preserve cellular energy budgets, as CEA remained unchanged. Overall, reductions in salinity from freshening appear more likely than elevated $\mathrm{CO}_{2}$ to reduce cellular energy budgets in a circumpolar arctic/subarctic species, which could have wider implications for fjord ecosystems in general. The low-salinity driven decrease in energy budgets, and in particular, protein and lipid energy reserves, suggests longer term implications for growth and reproductive fitness in amphipods from the lower-salinity populations within Kongsfjorden. However, the 28-day exposure period could be considered a short time frame over which responses can occur and therefore longer-term and trans-generational experiments are also needed to fully understand whether further adjustments can occur within and across generations. Studies are now underway to investigate the added effects of increased temperature, to further investigate whether G. setosus will be able to survive the full range of environmental changes occurring in fjord ecosystems, such as those represented by Kongsfjorden-Krossfjorden in Svalbard.

\section{Funding}

This work is part of IMR project 14591-04, Natural Analogues of an Arctic in Rapid Transition (AnalogueART) led by SPSR. Funded by FRAM-High North Research Centre for Climate and Environment Flagship program Ocean acidification and ecosystem effects in Northern Waters, awarded to HH, NMW and SPSR.

\section{Acknowledgments}

We would like to thank the staff at the NPI station in Ny-Ålesund and at the IMR station in Austevoll for their assistance in the collection of field and aquarium data. 
Benson, B. B., Krause Jr, D., 1984. The concentration and isotopic fractionation of oxygen dissolved in freshwater and seawater in equilibrium with the atmosphere 1. Limnology and Oceanography 29, 620-632.

Bligh, E. G., Dyer, W. J., 1959. A rapid method of total lipid extraction and purification. Canadian journal of biochemistry and physiology 37(8), 911-917.

Bolt, S. R. L., 1983. Haemolymph concentration and apparent permeability in varying salinity conditions of Gammarus duebeni, Chaetogammarus marinus and Gammarus locusta. Journal of Experimental Biology 107, 129-140.

Borges, F. O., Sampaio, E., Figueiredo, C., Rosa, R., Grilo, T. F., 2018. Hypercapnia-induced disruption of long-distance mate-detection and reduction of energy expenditure in a coastal keystone crustacean. Physiology \& behavior 195, 69-75.

Brooks, S. J., Mills, C. L., 2006. Gill $\mathrm{Na}^{+}, \mathrm{K}^{+}$-ATPase in a series of hyper-regulating gammarid amphipods. Enzyme characterisation and the effects of salinity acclimation. Comparative Biochemistry and Physiology Part A: Molecular \& Integrative Physiology 144, 24-32.

Caldeira, K., Wickett, M. E., 2003. Anthropogenic carbon and ocean pH. Nature 425, 365-365.

Callaghan, T. V., Johansson, M., Key, J., Prowse, T., Ananicheva, M., Klepikov, A., 2011. Feedbacks and interactions: From the Arctic cryosphere to the climate system. Ambio, 40, 75-86.

Calosi, P., Rastrick, S. P., Lombardi, C., De Guzman, H. J., Davidson, L., Jahnke, M., Giangrande, A., 2013. Adaptation and acclimatization to ocean acidification in marine ectotherms: an in-situ transplant experiment with polychaetes at a shallow $\mathrm{CO}_{2}$ vent system. Philosophical Transactions of the Royal Society B: Biological Sciences 368, 20120444.

Costa, F. O., Henzler, C. M., Lunt, D. H., Whiteley, N. M., Rock, J., 2009. Probing marine Gammarus (Amphipoda) taxonomy with DNA barcodes. Systematics and Biodiversity 7, 365-379.

D’Abramo, L. R., Conklin, D. E., Akiyama, D. M., 1997. Crustacean nutrition. Advances in world aquaculture, volume 6. Prepared by the International Working Group on Crustacean Nutrition. World Aquaculture Society, Louisiana, USA.

De Coen, W. M., Janssen, C. R., 1997. The use of biomarkers in Daphnia magna toxicity testing. IV. Cellular energy allocation: a new methodology to assess the energy budget of toxicant-stressed Daphnia populations. Journal of Aquatic Ecosystem Stress and Recovery 6, 43-55.

Dorgelo, J., 1973. Comparative ecophysiology of gammarids (Crustacea: Amphipoda) from marine, brackish and fresh-water habitats exposed to the influence of salinitytemperature combinations. III. Oxygen uptake. Netherlands Journal of Sea Research 7, 253-266. 
Fehsenfeld, S., Weihrauch, D., 2016. Mechanisms of acid-base regulation in seawateracclimated green crabs (Carcinus maenas). Canadian Journal of Zoology 94, 95-107.

Fraser, K. P., Rogers, A. D., 2007. Protein metabolism in marine animals: the underlying mechanism of growth. Advances in Marine Biology 52, 267-362.

Gnaiger, E., 1983. Calculation of energetic and biochemical equivalents of respiratory oxygen consumption, in: Gnaiger, E., Forstner, H. (Eds.), Polarographic Oxygen Sensors, Springer, Berlin, pp. 337-345.

Gómez, M., Torres, S., Hernández-León, S. 1996. Modification of the electron transport system (ETS) method for routine measurements of respiratory rates of zooplankton. South African Journal of Marine Science, 17, 15-20.

Goolish, E. M., Burton, R. S., 1989. Energetics of osmoregulation in an intertidal copepod: Effects of anoxia and lipid reserves on the pattern of free amino accumulation. Functional Ecology 3, 81-89.

Gulliksen, B., Beuchel, F., Brattegard, T., Palerud, R., 2003. The marine sublittoral fauna of Jan Mayen Island, in: Skreslet, S. (Eds.), Jan Mayen Island in scientific focus. NATO Science Series (Series IV: Earth and Environmental Sciences), Springer, Dordrecht, pp. 159-171.

Hammer, K. M., Pedersen, S. A., Størseth, T. R., 2012. Elevated seawater levels of CO2 change the metabolic fingerprint of tissues and hemolymph from the green shore crab Carcinus maenas. Comparative Biochemistry and Physiology Part D: Genomics and Proteomics 7, 292-302.

Henry, R. P., Lucu, C., Onken, H., Weihrauch, D., 2012. Multiple functions of the crustacean gill: osmotic/ionic regulation, acid-base balance, ammonia excretion, and bioaccumulation of toxic metals. Frontiers in Physiology 3, 431.

Houlihan, D. F., Carter, C. G., McCarthy, I. D., 1995. Protein synthesis in animals, in: Walsh, P., Wright, P. (Eds.), Nitrogen Metabolism and Excretion, CRC Press, Florida, pp. 1-32.

Ingólfsson, A., 1977. Distribution and habitat preferences of some intertidal amphipods in Iceland. Museum of Natural History: available from Snæbjörn Jonsson \& Company.

Intanai, I., Taylor, E. W., Whiteley, N. M., 2009. Effects of salinity on rates of protein synthesis and oxygen uptake in the post-larvae and juveniles of the tropical prawn Macrobrachium rosenbergii (de man). Comparative Biochemistry and Physiology Part A: Molecular and Integrative Physiology 152, 372-378.

Jimenez, A. G., Kinsey, S. T., 2015. Energetics and metabolic regulation, in: Chang, E. S., Thiel, M. (Eds.), The natural history of the Crustacea. Volume 4: Physiology. Oxford University Press, Oxford, pp. $391-419$.

Kelley, A. L., Lunden, J. J., 2017. Meta-analysis identifies metabolic sensitivities to ocean acidification Running title: Ocean acidification impacts metabolic function. AIMS Environmental Science 4, 709-729. 
Leinaas, H. P., Ambrose Jr. W. G., 1999. Decision between small and large prey: reduced energy acquisition by pre-migratory purple sandpipers, Callidris maritima, on Svalbard. Polar Biology 22(4), 264-270.

Lenth, R. V., 2016. Least-squares means: the R package 1smeans. Journal of Statistical Software 69, 1-33.

Lewis, E., Wallace, D. W. R., 1998. Program developed for $\mathrm{CO}_{2}$ system calculations. Oak Ridge National Laboratory, Carbon Dioxide Information Analysis Center. Report ORNL/CDIAC-105. US Department of Energy, Oak Ridge

Leyva, A., Quintana, A., Sánchez, M., Rodríguez, E. N., Cremata, J., Sánchez, J. C., 2008. Rapid and sensitive anthrone-sulfuric acid assay in microplate format to quantify carbohydrate in biopharmaceutical products: Method development and validation. Biologicals 36, 134-141.

Lincoln, R., 1979. British Marine Amphipoda: Gammaridea. British Museum (Natural History), London.

Lockwood, A. P. M., Inman, C. B. E., 1973. Water uptake and loss in relation to the salinity of the medium in the amphipod crustacean Gammarus duebeni. Journal of Experimental Biology 58, 149-163.

Lucu, Č., Towle, D. W., 2003. Na+ K+-ATPase in gills of aquatic crustacea. Comparative Biochemistry and Physiology Part A: Molecular \& Integrative Physiology, 135, 195-214.

McCormick, S. D., Bern, H. A., 1989. In vitro stimulation of $\mathrm{Na}^{+}-\mathrm{K}^{+}$-ATPase activity and ouabain binding by cortisol in coho salmon gill. American Journal of PhysiologyRegulatory, Integrative and Comparative Physiology 256, R707-R715.

Menu-Courey, K., Noisette, F., Piedalue, S., Daoud, D., Blair, T., Blier, P. U., Azetsu-Scott, K., Calosi, P. 2019. Energy metabolism and survival of the juvenile recruits of the American lobster (Homarus americanus) exposed to a gradient of elevated seawater pCO2. Marine environmental research 143, 111-123.

Normant, M., Schmolz, E., Lamprecht, I., 2004. Heat production rate of the Baltic amphipod Gammarus oceanicus at varying salinities. Thermochimica Acta 415, 135-139.

Normant, M., and Lamprecht, I., 2006. Does scope for growth change as a result of salinity stress in the amphipod Gammarus oceanicus? Journal of Experimental Marine Biology and Ecology 334, 158-163.

Orr, J. C., Fabry, V. J., Aumont, O., Bopp, L., Doney, S. C., Feely, R. A., Gnanadesikan, A., Gruber, N., Ishida, A., Joos, F., Key, R. M., Lindsay, K., Maier-Reimer, E., Matear, R., Monfray, P., Mouchet, A., Najjar, R. G., Plattner, G.-K., Rodgers, K.B., Sabine, C. L., Sarmiento, J. L., Schlitzer, R., Slater, R.D., Totterdell, I. J., Weirig, M. -F., Yamanaka, Y., Yool, A., 2005. Anthropogenic ocean acidification over the twenty-first century and its impact on calcifying organisms. Nature 437, 681-686.

Owens, T. G., King, F. D., 1975. The measurement of respiratory electron-transport-system activity in marine zooplankton. Marine Biology 30, 27-36. 
Pan, T. C. F., Applebaum, S. L., Manahan, D. T., 2015. Experimental ocean acidification alters the allocation of metabolic energy. Proceedings of the National Academy of Sciences $112,4696-4701$.

Pinheiro, J. C., Bates, D. M., 2000. Mixed-effects Models in S and S-PLUS. Springer, New York. USA. 528 p.

Ramaglia, A. C., de Castro, L. M., Augusto, A., 2018. Effects of ocean acidification and salinity variations on the physiology of osmoregulating and osmoconforming crustaceans. Journal of Comparative Physiology B 188, 729-738.

Rastrick, S. P. S., Whiteley, N. M., 2011. Congeneric amphipods show differing abilities to maintain metabolic rates with latitude. Physiological and Biochemical Zoology 84, 154165.

Rastrick, S. P. S., Whiteley, N. M., 2013. Influence of natural thermal gradients on whole animal rates of protein synthesis in marine gammarid amphipods. PloS one 8(3), 1-12.

Rastrick, S. P. S., Whiteley, N. M., 2017. Comparison of whole animal costs of protein synthesis among polar and temperate populations of the same species of gammarid amphipod. Comparative Biochemistry and Physiology Part A: Molecular \& Integrative Physiology 207, 100-106.

Rastrick, S. P., Collier, V., Graham, H., Strohmeier, T., Whiteley, N. M., Strand, Ø., 2018a. Feeding plasticity more than metabolic rate drives the productivity of economically important filter feeders in response to elevated $\mathrm{CO}_{2}$ and reduced salinity. ICES Journal of Marine Science 75(6), 2117-2128.

Rastrick, S. S., Graham, H., Azetsu-Scott, K., Calosi, P., Chierici, M., Fransson, A., Hop, H., Hall-Spencer, J., Milazzo, M., Thor, P., Kutti, T. 2018b. Using natural analogues to investigate the effects of climate change and ocean acidification on Northern ecosystems. ICES Journal of Marine Science, 75(7), 2299-2311.

Rivera-Ingraham, G. A., Lignot, J. H., 2017. Osmoregulation, bioenergetics and oxidative stress in coastal marine invertebrates: raising the questions for future research. Journal of Experimental Biology 220, 1749-1760.

Roe, J. H., 1954. The determination of sugar in blood and spinal fluid with anthrone reagent. Journal of Biological Chemistry 212, 335-343.

RStudio Team 2016. RStudio: Integrated development environment for R. Boston, MA.

Salin, K., Auer, S. K., Rudolf, A. M., Anderson, G. J., Cairns, A. G., Mullen, W., Hartley, R. C., Selman, C., Metcalfe, N. B., 2015. Individuals with higher metabolic rates have lower levels of reactive oxygen species in vivo. Biology Letters 11, 20150538.

Small, D. P., Calosi, P., Rastrick, S. P., Turner, L. M., Widdicombe, S., Spicer, J. I., 2020. The effects of elevated temperature and $\mathrm{PCO} 2$ on the energetics and haemolymph $\mathrm{pH}$ homeostasis of juveniles of the European lobster, Homarus gammarus. Journal of Experimental Biology 223, 1-10. 
Sokolova, I., 2018. Mitochondrial adaptations to variable environments and their role in animals' stress tolerance. Integrative and comparative biology, 58: 519-531.

Sokolova, I. M., Frederich, M., Bagwe, R., Lannig, G., Sukhotin, A. A., 2012. Energy homeostasis as an integrative tool for assessing limits of environmental stress tolerance in aquatic invertebrates. Marine environmental research, 79, 1-15.

Steele, V. J., Steele, D. H., 1970. The biology of Gammarus (Crustacea, Amphipoda) in the northwestern Atlantic. II. Gammarus setosus Dementieva. Canadian Journal of Zoology 48, 659-671.

Steinacher, M., Joos, F., Frölicher, T. L., Plattner, G. K., Doney, S. C., 2009. Imminent ocean acidification in the Arctic projected with the NCAR global coupled carbon cycle-climate model. Biogeosciences, 6, 515-533.

Sutcliffe, D. W., 1984. Quantitative aspects of oxygen uptake by Gammarus (Crustacea, Amphipoda): a critical review. Freshwater Biology 14, 443-489.

Svendsen, H., Beszczynska-Møller, A., Hagen, J. O., Lefauconnier, B., Tverberg, V., Gerland, S., Ørbøk, J. B., Bischof, K., Papucci, C., Zajaczkowski, M., Azzolini, R., Bruland, O., Wiencke, C., Winther, J. -G., Dallmann, W., 2002. The physical environment of Kongsfjorden-Krossfjorden, an Arctic fjord system in Svalbard. Polar Research 21, 133166.

Torres, G., Giménez, L., Anger, K., 2007. Effects of osmotic stress on crustacean larval growth and protein and lipid levels are related to life-histories: the genus Armases as a model. Comparative Biochemistry and Physiology Part B: Biochemistry and Molecular Biology 148, 209-224.

Tverberg, V., Skogseth, R., Cottier, F., Sundfjord, A., Walczowski, W., Inall, M. E., Falck, E., Pavlova, O., Nilsen, F., 2019. The Kongsfjorden transect: seasonal and inter-annual variability in hydrography, in: Hop, H., Wiencke, C. (Eds.), The Ecosystem of Kongsfjorden, Svalbard. Springer, Cham, pp. 49-104.

Vader, W., Tandberg, A. H., 2019. Gammarid amphipods (Crustacea) in Norway, with a key to the species. Fauna Norvegica 39, 12-25.

Van Vuuren, D. P., Edmonds, J., Kainuma, M., Riahi, K., Thomson, A., Hibbard, K., Hurtt, G. C., Kram, T., Krey, V., Lamarque, J. -F., Masui, T., Meinshausen, M., Nakicenovic, N., Smith, S. J., Rose, S. K. 2011. The representative concentration pathways: an overview. Climatic Change 109, 5.

Vihtakari, M., 2019. PlotSvalbard: PlotSvalbard - Plot research data from Svalbard on maps. $\mathrm{R}$ package version 0.8 .5 .

Weslawski, J. M., Draganska-Deja, K., Legezynska J., Walczowski W., 2018. Range extension of a boreal amphipod Gammarus oceanicus in the warming Arctic. Ecology and Evolution 8, 7624-7632.

Węsławski, J. M., Kendall, M. A., Włodarska-Kowalczuk, M., Iken, K., Kędra, M., Legezynska, J., Sejr, M. K., 2011. Climate change effects on Arctic fjord and coastal macrobenthic diversity—observations and predictions. Marine Biodiversity 41, 71-85. 
Wheatly, M. G., Henry, R. P., 1992. Extracellular and intracellular acid-base regulation in crustaceans. Journal of Experimental Zoology, 263(2), 127-142.

Whiteley, N. M., 2011. Physiological and ecological responses of crustaceans to ocean acidification. Marine Ecology Progress Series 430, 257-271.

Whiteley, N. M., Scott, J. L., Breeze, S. J., McCann, L., 2001. Effects of water salinity on acidbase balance in decapod crustaceans. Journal of Experimental Biology, 204(5), 10031011.

Whiteley, N. M., Suckling, C. C., Ciotti, B. J., Brown, J., McCarthy, I. D., Gimenez, L., Hauton, C., 2018. Sensitivity to near-future $\mathrm{CO}_{2}$ conditions in marine crabs depends on their compensatory capacities for salinity change. Scientific Reports 8, 1-13.

Widdicombe, S., Spicer, J. I., 2008. Predicting the impact of ocean acidification on benthic biodiversity: what can animal physiology tell us?. Journal of Experimental Marine Biology and Ecology, 366(1-2), 187-197.

Wilder, M. N., Atmomarsono, M., Hien, T. T. T., Phu, T. Q., Yang, W. J., 2000. Characterization of $\mathrm{Na} / \mathrm{K}$-ATPase in Macrobrachium rosenbergii and the effects of changing salinity on enzymatic activity. Comparative Biochemistry and Physiology Part A: Molecular \& Integrative Physiology 125, 377-388.

Wittmann, A. C., Pörtner, H.-O., 2013. Sensitivities of extant animal taxa to ocean acidification. Nature Climate Change 3, 995-1001.

Wood, H. L., Sundell, K., Almroth, B. C., Sköld, H. N., Eriksson, S. P., 2016. Populationdependent effects of ocean acidification. Proceedings of the Royal Society B: Biological Sciences 283, 20160163.

Zuur, A. F., Ieno, E. N., Walker, N. J., Saveliev, A. A., Smith, G., M., 2009. Mixed effects models and extensions in ecology with R. Springer, New York, USA. 574 p.

(1) 